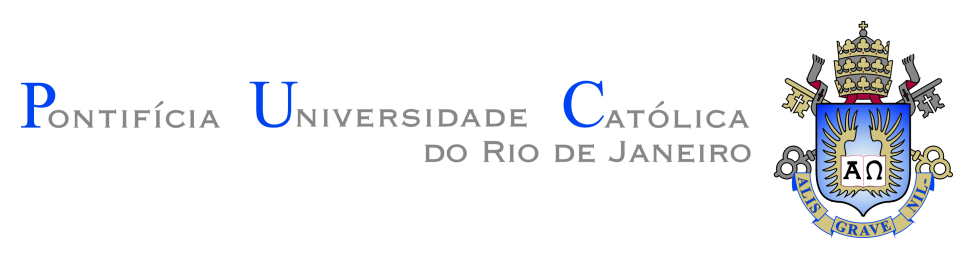

Matheus Almeida Dalalana D' Amico

The tax benefits of Interest on Equity: Why so many firms forgo them?

Dissertação de Mestrado

Dissertation presented to the Programa de Pós-graduação em Economia da PUC-Rio in partial fulfillment of the requirements for the degree of Mestre em Economia.

Advisor: Prof. Walter Novaes

Rio de Janeiro

April 2019 


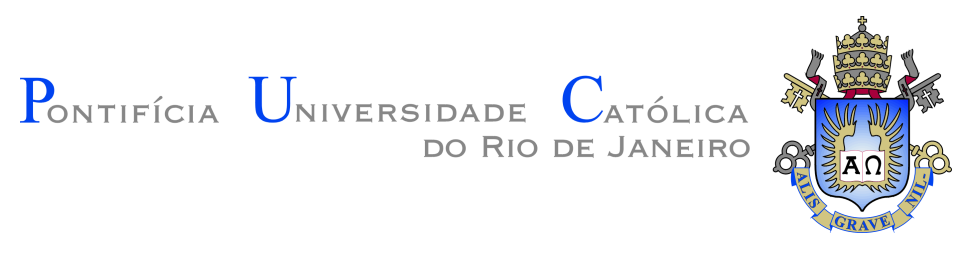

Matheus Almeida Dalalana D' Amico

\section{The tax benefits of Interest on Equity: Why so many firms forgo them?}

Dissertation presented to the Programa de Pós-graduação em Economia da PUC-Rio in partial fulfillment of the requirements for the degree of Mestre em Economia. Approved by the undersigned Examination Committee.

Prof. Walter Novaes

Advisor

Departamento de Economia - PUC-Rio

Prof. Ruy Monteiro Ribeiro

Departamento de Economia - PUC-Rio

Prof. Patrick Gottfried Behr

Escola Brasileira de Administração Pública e de Empresas FGV/EBAPE 
All rights reserved.

\section{Matheus Almeida Dalalana D' Amico}

B.A., Economics, Pontifícia Universidade do Rio de Janeiro (PUC-Rio), 2016

Bibliographic data

Dalalana D' Amico, Matheus Almeida

The tax benefits of Interest on Equity: Why so many firms forgo them? / Matheus Almeida Dalalana D' Amico; advisor: Walter Novaes. - Rio de janeiro: PUC-Rio, Departamento de Economia, 2019.

v., 68 f: il. color. ; $30 \mathrm{~cm}$

Dissertação (mestrado) - Pontifícia Universidade Católica do Rio de Janeiro, Departamento de Economia.

Inclui bibliografia

1. Economia - Teses. 2. Economia - Teses. 3. Juros sobre Capital Próprio;. 4. Alíquota de Imposto de renda sobre pessoa jurídica;. 5. Problemas de Agência.. I. Novaes, Walter. II. Pontifícia Universidade Católica do Rio de Janeiro. Departamento de Economia. III. Título. 
ป

To my parents, brother and sister. 


\section{Acknowledgments}

First, I would like to thank my research advisor, Professor Walter Novaes, not only for his professionalism devoted to this dissertation, but also for playing a fundamental role on shaping my formation along my masters and undergraduate studies. I will always be grateful for all invaluable opportunities and lessons granted for me during these years I spent in PUC-Rio.

I thank Professor Ruy Ribeiro for helping on developing my formation in Finance and for all great opportunities offered. I also thank him for his helpful insights on this work. I thank professor Patrick Behr for accepting the invite to be on the Examination Committee and for his valuable insights.

I thank my family for all support without which I wouldn't be able to go on. Specially my father, for always believing in my potential and granting me the necessary conditions to proceed with my studies. I thank Luiza, for the immeasurable partnership and comprehension through the toughest moments. I also thank my friends for the technical help and moments of fun that made this masters easier.

Finally, I thank ANBIMA for recognizing this work and for the financial support through the "XIV Prêmio ANBIMA de Mercado de Capitais". "This study was financed in part by the Coordenação de Aperfeiçoamento Pessoal de Nível Superior - Brasil (CAPES) - Código de Financiamento 001" 


\section{Abstract}

Dalalana D' Amico, Matheus Almeida; Novaes, Walter (Advisor). The tax benefits of Interest on Equity: Why so many firms forgo them?. Rio de Janeiro, 2019. 68p. Dissertação de mestrado - Departamento de Economia, Pontifícia Universidade Católica do Rio de Janeiro.

From 1996 on, tax laws in Brazil allow firms to distribute cash to its shareholders in two ways: dividend payments and interest on equity. Firms that pay interest on equity can deduct them for tax purposes, but they cannot deduct dividend payments. Investors, in turn, do not pay taxes on the dividends they earn, but they do pay on the amount of interest on equity they receive. All in all, there is a tax advantage in paying interest on equity instead of dividends. And yet, many public firms in Brazil forgo the tax benefits of interest on equity. I argue that an agency problem explains this puzzle. If a firm pays dividends, the tax cost of forgoing the corporate tax deduction of interest on equity is split among all shareholders. In contrast, controlling shareholders bear most of the taxes on interest on equity, if the paying firm has a pyramidal ownership structure. I present evidence that this asymmetry on the tax burden may indeed explain why so many firms in Brazil pay dividends instead of interest on equity.

\section{Keywords}

Interest on Equity; Corporate tax rate; Agency Problems. 


\section{Resumo}

Dalalana D' Amico, Matheus Almeida; Novaes, Walter. Os Benefícios Fiscais dos Juros sobre o Capital Próprio: Por que tantas firmas os dispensam?. Rio de Janeiro, 2019. 68p. Dissertação de Mestrado - Departamento de Economia, Pontifícia Universidade Católica do Rio de Janeiro.

Desde 1996, a legislação fiscal brasileira permite que as empresas distribuam lucros para os seus acionistas em duas maneiras distintas: Dividendos e Juros sobre o Capital Próprio. Os Juros sobre o Capital Próprio pagos aos acionistas são dedutíveis do imposto de renda da firma pagadora, mas são tributados no nível do acionista beneficiário. Os dividendos pagos, por outro lado, não podem ser deduzidos do imposto de renda da firma pagadora, mas em contrapartida, não são tributados ao nível do acionista. Tudo o mais, há uma vantagem fiscal em distribuir lucros em Juros sobre o Capital Próprio ao invés de dividendos. Entretanto, muitas empresas brasileiras de capital aberto dispensam essa vantagem fiscal ao distribuir lucros exclusivamente via dividendos. Eu proponho que problemas de agência seriam responsáveis por esse puzzle. Caso uma firma opte por pagar dividendos, os custos fiscais de não distribuir lucros em Juros sobre Capital Próprio são igualmente divididos entre todos os acionistas. Os acionistas controladores, por outro lado, arcam com grande parte do ônus fiscal dos Juros sobre o Capital Próprio recebidos caso a firma possua uma estrutura acionária piramidal. Apresento evidência de que tal assimetria na distribuição dessa carga fiscal pode ser a razão pela qual tantas firmas abdicam de distribuir lucros via Juros sobre Capital Próprio.

\section{Palavras-chave}

Juros sobre Capital Próprio; Alíquota de Imposto de renda sobre pessoa jurídica; Problemas de Agência. 


\section{Table of contents}

1 Introduction $\quad 11$

2 Legal Framework of Interest on Equity and the Agency Problem $\quad 16$

2.1 Legal Framework of Interest on Equity 16

2.2 Value Maximization or Agency Problem? 17

3 Database and Descriptive Statistics 22

3.1 Database 22

3.2 Descriptive Statistics 24

4 Agency Problem Relevancy $\quad 27$

$5 \quad$ Empirical Strategy, Results and Robustness Checks 31

5.1 Empirical Strategy 31

$\begin{array}{lll}5.2 & \text { Results } & 35 \\ 5.3 & \text { Robustness Checks } & 35\end{array}$

5.3 Robustness Checks 36

$6 \quad$ Validation of the Regression Discontinuity Design 39

7 Conclusions $\quad 42$

A Tables $\quad 46$

$\begin{array}{lll}\text { B Figures } & 61\end{array}$ 


\section{List of figures}

Figure B.1 Cash distribution by eligible firms to pay Interest on Equity 61

Figure B.2 Discontinuity in the probability of paying IOE at the

0.228625 cutoff for the full sample

Figure B.3 Discontinuity in the probability of paying IOE at the

0.228625 cutoff for firms in Ordinary Segments

Figure B.4 Discontinuity in the probability of paying IOE at the

0.228625 cutoff for firms in Premium Segments

Figure B.5 Discontinuity of Assets at the 0.228625 cutoff 64

Figure B.6 Discontinuity of Capex at the 0.228625 cutoff 64

Figure B.7 Discontinuity of Tobin's Q at the 0.228625 cutoff 65

Figure B.8 Discontinuity of Leverage at the 0.228625 cutoff 65

Figure B.9 Discontinuity of Retained Earnings at the 0.228625 cutoff 66

Figure B.10 Discontinuity of Equity at the 0.228625 cutoff 66

Figure B.11 Discontinuity of Profitability at the 0.228625 cutoff $\quad 67$

Figure B.12 Discontinuity of the First Lag of the outcome variable at the 0.228625 cutoff $\quad 67$

Figure B.13 Histogram of the Corporate tax rate 68

Figure B.14 Estimated Density of the Corporate tax rate 68 


\section{List of tables}

Table 2.1 Payoffs by cash distribution and shareholder type

Table A.1 Characteristics between Interest on Equity and Dividend payers

46

Table A.2 Probit Regression

Table A.3 Control of publicly traded firms at the moment of the oldest available public distribution of securities by listing segments.

Table A.4 Frequency by which ultimate shareholder controls the firms of our sample through a corporation that is not an investment fund

Table A.5 Frequency by which ultimate shareholder controls the firms of our sample through a corporation that is not an investment fund by listing segments

Table A.6 Voting Rights versus Cash Flow Rights of the ultimate controlling shareholder

Table A.7 Voting Rights versus Cash Flow Rights of the ultimate controlling shareholder by listing segments

Table A.8 Individuals $(1-\alpha-\beta)$ and Investment Fund $(\beta)$ Minority shareholder's cash flow rights descriptive statistics

Table A.9 Total cash flow rights of shareholders who are corporations $\left(\alpha=\alpha_{1}+\alpha_{2}\right)$ descriptive statistics

Table A.10 Sharp Regression Discontinuity Design estimates for the full sample around the 0.228625 cutoff value of the corporate tax rate

Table A.11 Sharp Regression Discontinuity Design estimates for Ordinary Segments around the 0.228625 cutoff value of the corporate tax rate

Table A.12 Sharp Regression Discontinuity Design estimates for Premium Segments around the 0.228625 cutoff value of the corporate tax rate

Table A.13 Sharp Regression Discontinuity Estimates around the 0.228625 cutoff using different Kernels (Robustness check 1)

Table A.14 Sharp Regression Discontinuity Estimates around the 0.228625 cutoff using different polynomial degrees (Robustness check 2)

Table A.15 Checking the local balancing of observable characteristics around the 0.228625 cutoff (First Validation test)

Table A.16 Sharp Regression Discontinuity Design using the first lag of the Probability of paying IOE as the dependent variable (Second Validation test)

Table A.17 McCrary Manipulation test (Third Validation test) 


\section{Introduction}

It comes without saying that firms should minimize the corporate taxes they pay. Miller (1977) argues that firms should also be concerned with the taxes paid by the investors that buy corporate securities. Miller's influential argument goes as follows: Rational investors understand that a fraction of their earnings will be captured by the government through taxes. By lowering these taxes, firms should be able to reduce the interest rate that their corporate securities pay, increasing firm value accordingly. Minimizing taxes on corporate cash flows should thus be a goal of value-maximizing firms, whether these taxes are paid by the firm or its security holders.

Merton Miller's argument spread quickly throughout the finance profession: academics and practitioners alike. And yet, Bagwell and Shoven (1989) provided evidence that tax-lowering schemes may benefit some security holders at the cost of others. Specifically, Bagwell and Shoven (1989) documented that back on the 1980s, several North American companies started substituting stock repurchases for dividends, although many firms didn't follow the wave and kept paying only cash dividends. At that time, there was a tax asymmetry on capital gains and dividends between shareholders. Indeed, retail investors were more heavily taxed on dividends than on capital gains, while Institutional Investors faced a higher tax burden on capital gains than on dividends. We suspect that this tax asymmetry probably lies behind the fact that some companies distributed a high fraction of its earnings in share repurchases although others didn't.

From Miller (1977)'s argument, we can infer that some companies didn't repurchase stocks back on the 1980s because the tax benefit incurred by its retail investors on receiving profits in repurchases would be outweighed by the tax burden faced by institutional investors. That is, for some companies, repurchasing shares wouldn't be worthwhile because that would reduce the total net tax value distributed to its shareholders.

An agency problem argument can make that reasoning questionable, though. Indeed, a natural question to be asked is: Who were the controlling shareholders of the companies that didn't distribute cash via repurchases ? If those controlling shareholders were institutional investors, it might be the 
case that these firms focused on the negative effects of stock repurchases on corporate insiders at the expense of the minority shareholders.

We conclude that two possible explanations could lie behind the fact that so many companies adopted repurchases to distribute profits and others didn't: ${ }^{1}$ A value maximizing justification and an agency problem one. How could we test which of these answers would prevail in practice?

Finding evidence for agency problems on the firm's tax strategies is not simple. In the aforementioned wave of stock repurchases, we would need data on the tax rates faced by shareholders on both dividends as well as on capital gains. Unfortunately, such data are not observable. Data to asses agency costs on tax strategies are observable, nonetheless, in a tax saving scheme in Brazil spurred by a 1995 law that allowed Brazilian firms to deduct cash payments to shareholders for tax purposes.

As in most western countries, firms in Brazil couldn't deduct payments for tax purposes, whilst financial expenses were (and still are) tax deductible. On December 1995, the Brazilian Congress passed a law that allowed firms to pay cash dividends to shareholders through a tax deductible instrument called "Interest on Equity". The rationale for the law was clear from the onset: Allow firms to reduce their total tax bill.

Although interest on equity is tax deductible at the corporate level, it is taxed at the shareholders' level on a $15 \%$ fixed rate. In case the shareholder is a corporation, it must face an additional tax burden of $9.25 \%$ over the $15 \%$ rate on interest on equity. Dividends, on the other hand, are not deductible at the corporate level, but are not taxed at the shareholder level.

Considering that the highest tax bracket faced by non-financial firms in Brazil is of $34 \%$, the fiscal benefits of distributing cash in interest on equity can reach $19 \%(34 \%-15 \%)$ if the shareholder being paid is an individual, and nearly $9.75 \%(34 \%-15 \%-9.25 \%)$ if the shareholder receiving interest on equity is a corporation. Because the tax rate faced by the shareholders are fixed, and the tax bracket of a company varies, the tax benefits of interest on equity positively varies with the company's tax bracket. Therefore, firms facing higher tax brackets are the ones that benefit the most from distributing profits in interest on equity.

Provided that the corporate tax rate faced by the paying company is low enough, the fiscal benefit of paying interest on equity might vanish. Indeed, we show that there is a minimum firm specific tax rate that makes it advantageous for a company to pay interest on equity instead of dividends. Besides, we

${ }^{1}$ Of course, another explanation is the signaling for tax clientele brought to light by Allen et al. (2000) 
also show that this tax rate is usually smaller than the minimum tax rate of $22.86 \%$ (see section 2.2) that makes the controlling shareholder better off when paid in interest on equity. Therefore, these two rates determine an interval of tax brackets in which the controlling shareholder would prefer to be paid in dividends, although the company would maximize value by distributing profits in interest on equity. The minimum tax rate that makes it optimal for the controlling shareholder to be paid in Interest on Equity is higher than the optimal one from the firm's perspective because the controlling shareholder usually structure its equity holdings through a chain of companies, making it subject to the extra tax layer of $9.25 \%$ on interest on equity revenues.

Perhaps, the tax-brackets of the Brazilian firms that only pay dividends fell short of allowing the interest on equity alternative to lower the combined tax bills of these firms and their shareholders. However, it might be the case that these firm's tax brackets are lower than the $22.86 \%$ tax rate that would make it optimal for the controlling shareholder to be paid in interest on equity. Indeed Lee-Ness (2001) documented that many public firms in Brazil forego the alternative of paying cash to shareholders in Interest on Equity, but we don't know if those companies are forgoing interest on equity because they are maximizing the total net tax value, or because of agency problems.

The $22.86 \%$ upper bound of the interval in which the agency problem is induced provides a natural threshold to test whether firms are forgoing interest on equity because they're maximizing value or because they are facing agency problems. In fact, in the absence of agency problems we should not find a statistically significant variation in the number of firms that pay Interest on Equity as we move from the group of firms with tax rates marginally above $22.86 \%$ to those with tax rates marginally below that value.

To explore this natural cutoff of $22.86 \%$, we apply a Sharp Regression Discontinuity Design on a sample of 335 public firms, listed at Brazil's stock exchange (B3), eligible for paying Interest on Equity and that paid cash to shareholders (either through dividends or interest on equity) in at least one year of the sample period that goes from 1996 to 2017.

Consistent with the relevance of the agency problem, we estimate a decrease of nearly $24 \%$ in the probability of paying interest on equity when firms cross the corporate tax rate of $22.86 \%$ from marginally above to below.

The discontinuity result does not hold in the subsample of firms listed in the Premium Segments of B3 that requires stricter governance standards. Presumably, firms that voluntarily conform to higher practices of corporate governance are probably less susceptible to agency problems.

Carvalho (2012) and Boulton et al. (2012) extended the findings of Lee- 
Ness (2001) by showing that the number of firms that pay Interest on Equity has increased from 1996 to 2007, but a large number of companies kept paying only dividends along those years. Carvalho (2012) argues that the low adhesion to interest on equity was due to an uncertainty on whether the extra layer of $9.25 \%$ on the tax burden would be upheld by the Supreme Court. Boulton et al. (2012), in turn, shows that firms in the Premium Segments of B3 and that have less tax shields are more likely to pay Interest on Equity.

Desai et al. (2007) suggested that transactions aimed at diverting value from outside shareholders to insiders also tended to reduce corporate taxes. Boulton et al. (2012) explored Desai et al. (2007)'s idea to suggest that the tax deductibility of interest on equity payments would be more valuable for those companies with highest standards of corporate governance because those companies would be less likely to divert value from outside shareholders, and therefore, reduce corporate tax liabilities.

Our contribution to the existing literature is twofold: First, we show that the asymmetric taxation of interest on equity revenues between shareholders can lead to agency problems on the decision of the firm's payout policy. Besides, we watch for the fact that for some companies it may not worth it to distribute profits in interest on equity depending on the firm's ownership structure and its corporate tax rate. In a nutshell, a firm can forgo interest on equity either because distributing profits in this way wouldn't maximize the total net tax value distributed or because it wouldn't maximize the net tax value destined to the controlling shareholder.

Even further, this dissertation provides a framework for identifying firms subject to agency problems in the adoption of any tax strategy in which the tax burden of this strategy varies between shareholders. The asymmetric taxation between controlling and minority shareholders will make the value maximizing decision differ from the decision that maximizes the controlling shareholder's net tax gains, which in turn will subject the firm to conflicts of interest of the same nature of those pointed out by Myers and Majluf (1984).

Notice the similarity between the relatively low adhesion of Brazilian firms to interest on equity (IOE from now on) with the abandonment of share repurchases by many North American companies back on the 1980s. Indeed, both instruments of cash distribution are taxed differently depending on the shareholder being paid, which makes both tax-lowering instruments susceptible to agency problems in it's implementations.

The paper proceeds as follows. Chapter 2 describes the legal framework underlying the Interest on Equity and formalizes the corporate tax rate threshold of the value maximizing decision of paying Interest on Equity as 
well as the threshold for the agency problem. Chapter 3 describes our data and presents some descriptive statistics. Chapter 4 provides evidence of the relevance of the agency problem. Chapter 5 explains the empirical strategy, presents the main results as well as an estimate of the average agency cost, and finishes with robustness checks. Chapter 6 is destined to the validation of the regression discontinuity design. Chapter 7 concludes. 


\section{2 \\ Legal Framework of Interest on Equity and the Agency Problem}

\section{1}

\section{Legal Framework of Interest on Equity}

Brazilian companies are allowed by Law to distribute cash to its shareholders in either dividends or interest on equity. The main difference between the interest on equity from the traditional dividends is that the former is tax deductible at the corporate level while the latter isn't. However, dividend revenues are tax exempt at the shareholder level, whereas interest on equity receipts are subject to a withholding tax rate of $15 \%$ if the shareholder being paid is an individual. For corporations, there is an additional tax burden of $9.25 \%$ on interest on equity over the $15 \%$ withholding rate. The only exception to that rule are shareholders who owns shares of the paying company through an Investment Fund (see Bonomo (2015)). In that case, the shareholder is tax exempt of the $15 \%$ tax rate over interest on equity revenues. Nevertheless, Investment Fund shareholders are still subject to the $9.25 \%$ rate on interest on equity revenues. ${ }^{1}$

Interest on equity was instituted as a way of profit distribution by Law $9.249 / 1995$, which became valid on January 1996. The Law's goal was to equalize the fiscal treatment of equity and debt, since financial expenses were tax deductible (and still are) at the corporate level. Therefore, legislators began to allow the deduction of cash flow distribution from the corporate taxes of the paying firm, provided that such distribution was made via Interest on Equity instead of dividends. The Interest on Equity to be paid is calculated as the product of the long-term interest rate determined by the National Monetary Council (which is known as TLP) by the company's book value of equity. In order to be tax deductible, the total amount of interest on equity distributed must be limited to the greatest of fifty percent of the current period's earnings

${ }^{1}$ That additional tax burden of $9.25 \%$ faced by shareholders who are corporations is related to the PIS and COFINS taxes. PIS and COFINS are taxes of $1.65 \%$ and $7.6 \%$, respectively, charged over Brazilian companies gross revenues. In Brazil, financial revenues are characterized as gross revenues, and interest on equity receipts must be accounted as financial revenues according to the Brazilian tax Law. 
before interest on equity payments and fifty percent of retained earnings plus earnings reserve before the current period's net profit. In Brazil, profitable companies are enforced by Law to distribute a minimum amount of cash to its shareholders, and interest on equity can be deducted from this minimum amount (see Martins and Novaes (2012) for details on mandatory dividend rules in Brazil).

\section{2}

\section{Value Maximization or Agency Problem?}

In order to explain the agency problem derived from the firms' cash flow distribution policy, consider a simple theoretical model in which we assume that a firm eligible to deduct interest on equity payments decided to distribute $\mathrm{R} \$ 1.00$ of its profits before taxes to its shareholders. We will be classifying the shareholders in three different types: Corporation shareholders, Investment Fund shareholders and Individual shareholders. The Corporation shareholders are those that owns shares through a corporation that is not an investment fund. The Investment Fund ones are those that owns shares through an investment fund, and the Individual shareholders are those individuals who directly owns shares of the company. The reason why we just consider these three types of shareholders is because of the different taxation rules (described on section 2.1) they face on Interest on Equity received. Our main hypothesis, which will be justified in chapter 4 , is that the controlling shareholder owns shares of the paying company through a corporation that is not an investment fund, i.e, the controlling shareholder is a Corporation.

Notice that a shareholder who indirectly owns shares of a firm do so through a chain of companies. It is worth emphasizing that we are classifying those shareholders who indirectly owns shares (Corporation and Investment Fund shareholders) based on the classification of the first company of the chain by which he structure his equity holdings. We do so because the first shareholder of the chain is the one who will receive the profit distributed by the paying firm. Because the ultimate shareholder of the paying company aims at maximizing his received profits, he will be interested at maximizing the total profits received by the first company of the chain through which he owns shares of the paying company.

Therefore, if the first firm of the chain by which a specific ultimate shareholder owns shares of the paying company is an Investment Fund, then this shareholder is classified as an Investment Fund. If that company is not an Investment Fund, then the ultimate shareholder is classified as a Corporation. 
Below we emphasize our hypothesis and the model's parameters. Notice that the cash flow rights parameters of the Corporations and Investment Funds shareholders are the ones of the first companies of the chain by which the ultimate shareholder owns shares of the paying firm. Once again, those first shareholders are the ones who will receive the distributed profits by the paying company.

- Hypothesis: The controlling shareholder is a Corporation.

$-\alpha_{1}$ : Cash flow rights of the controlling shareholder.

- $\alpha_{2}$ : Cash flow rights of minority shareholders who are Corporations

- $\beta$ : Cash flow rights of minority shareholders who are Investment Funds.

- $\left(1-\alpha_{1}-\alpha_{2}-\beta\right)$ : Cash flow rights of minority shareholders who are Individuals.

$-t_{C}$ : Effective corporate tax rate faced by the paying firm.

We denote the total cash flow rights of shareholders who are Corporations (the sum of controlling and minority ones) by $\alpha$, i.e, $\alpha=\alpha_{1}+\alpha_{2}$. Therefore, we can simplify the cash flow rights of the minority shareholders who are Individuals by $(1-\alpha-\beta)$.

In the table below, we present the net tax gains for the four different kinds of shareholders by the type of proceeds (interest on equity and dividends). Notice that the $\mathrm{R} \$ 1.00$ profit, if distributed in dividends, will be reduced in $t_{C}$ because dividends are not tax deductible at the corporate level. The amount received by the shareholders, $\left(1-t_{C}\right)$, has to be multiplied by their cash flow rights.

If this $\mathrm{R} \$ 1.00$ is distributed in IOE, the tax deduction at the level of the paying company permits both minority and controlling shareholders to receive $\mathrm{R} \$ 1.00$. However, the shareholders who are individuals should bear a $15 \%$ withholding tax rate, while both controlling and minority shareholders who are corporations should bear the $15 \%$ withholding tax added by the $9.25 \%$ rate. Finally, the investment fund is exempt from paying the $15 \%$ tax rate on interest on equity received, but still needs to pay the $9.25 \%$ tax rate. All net tax payoffs must be multiplied by the shareholder cash flow rights.

An agency problem will arise when the firm's total net gain because of the $\mathrm{R} \$ 1.00$ received in IOE exceeds the total net gain resulting from the distribution via dividends, and, at the same time, the net gain of the controlling shareholder in receiving profits on IOE is lower than his gain if paid by 


\begin{tabular}{c|cc} 
Shareholder Type & Dividends & Interest on Equity \\
\hline Minority Individuals & $(1-\alpha-\beta)\left(1-t_{C}\right)$ & $(1-\alpha-\beta)(1-0.15)$ \\
Minority Corporations & $\alpha_{2}\left(1-t_{C}\right)$ & $\alpha_{2}(1-0.15)(1-0.0925)$ \\
Minority Investment Funds & $\beta\left(1-t_{C}\right)$ & $\beta(1-0.0925)$ \\
Controlling & $\alpha_{1}\left(1-t_{C}\right)$ & $\alpha_{1}(1-0.15)(1-0.0925)$ \\
Total & $\left(1-t_{C}\right)$ & $0.0575 \beta+0.85(1-\alpha 0.0925)$
\end{tabular}

Table 2.1: Payoffs by cash distribution and shareholder type

dividends. Next, I will present the inequalities that summarize the situation in which the agency problem arises.

1. Paying Interest on Equity is profit maximizing:

$$
0.0575 \beta+0.85(1-\alpha 0.0925) \geq\left(1-t_{C}\right)
$$

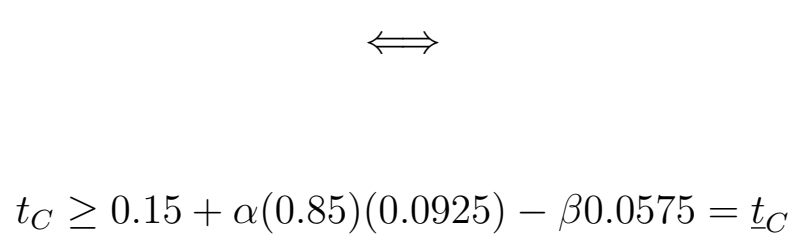

2. Controlling shareholder prefers receiving dividends rather than interest on equity:

$$
\begin{gathered}
\alpha_{1}\left(1-t_{C}\right)>\alpha_{1}(1-0.15)(1-0.0925) \\
\Longleftrightarrow \\
t_{C}<1-(0.85)(0.9075)=0.228625=\bar{t}_{C}
\end{gathered}
$$

3. Agency Costs arises:

$$
t_{C} \in[0.15+\alpha(0.85)(0.0925)-\beta 0.0575 ; 0.228625]=\left[\underline{t}_{C} ; \bar{t}_{C}\right]
$$

Notice that the interval's lower bound,$\underline{t}_{C}$, is the tax rate that determines the optimal payout policy for the company, while the interval's upper bound, $\bar{t}_{C}$, determines the optimal payout policy for the controlling shareholder. That tax asymmetry is precisely what drives the agency problem. As a matter of fact, 
a firm concerned with the maximization of the total value of profits distributed would choose to pay interest on equity provided that the effective corporate tax rate is higher than $\underline{t}_{C}$, while it would opt to distribute profits in dividends if the corporate tax rate is lower than $\underline{t}_{C}$. That value maximizing decision doesn't coincides with the optimal one from the controlling shareholder point of view. Indeed, the controlling shareholder would maximize its net tax gains if it received profits in interest on equity when the corporate tax rate is higher than $\bar{t}_{C}=0.2286$, and received profits in dividends otherwise.

Besides, $\bar{t}_{C}=0.2286$ determines the optimal payout policy for the shareholders who are corporations, be it controlling or minority. Therefore, if the firm was fully owned through corporations that are not investment funds, no tax asymmetry would arise, and thereof, that agency problem wouldn't exist. The different taxation rules on interest on equity between classifications of shareholders is what leads to the agency problem in the payout policy. That tax asymmetry will prevail only if the ownership structure of the paying company is enough diversified, i.e, if the cash flow rights of the minority shareholders that are classified differently from the controlling one are substantially different from zero.

In the case in which the corporate tax rate belongs to the interval $\left[\underline{t}_{C} ; \bar{t}_{C}\right]$ that encourages the agency problem, and assuming that the controlling shareholder exercises his voting power to determine the cash distribution via dividends, the loss in the value distributed by the firm, the agency cost, would be given by the following expression:

$$
\text { Agency Cost }=0.0575 \beta+0.85(1-\alpha 0.0925)-\left(1-t_{C}\right)
$$

The agency cost is given by the difference of the firm's value that would prevail from the optimal cash flow distribution policy from the firm's perspective and the optimal one from the controlling shareholder, but suboptimal to the firm.

The agency cost is a decreasing function of the parameter $\alpha$, which measures the total cash flow rights of shareholders who are corporations. ${ }^{2}$ That is so, because if the total cash flow rights of this shareholders who are corporations are too small, their benefits on receiving profits via dividends would be outweighed by the opportunity cost of the other shareholders, that

\footnotetext{
${ }^{2}$ More precisely, the agency cost is a decreasing function of $\alpha$ provided that $\alpha \in\left(\begin{array}{ll}0 & 1\end{array}\right)$. In fact, if $\alpha=0$, the controlling shareholder would be indifferent to the distribution policy, since he wouldn't receive nothing in any case. Similarly, if $\alpha=1$, the optimal choice from the controlling shareholder would coincide with the firm's optimal choice. In any case, $\alpha=$ 0 or $\alpha=1$, there would be no agency problem.
} 
are not corporations, of being paid via dividends instead of IOE. Moreover, the agency cost is an increasing function of the parameter $\beta$, which denotes the cash flow rights of the minority shareholders who owns shares through an investment fund. Indeed, these shareholders are the ones that most benefit from being paid in Interest on Equity because of the 15\% tax exemption.

From what is exposed above, we can conclude that the agency problem would be empirically relevant only if we could justify that the controlling shareholder is usually a corporation, and that the total cash flow rights from the minority shareholders that are not corporations,i.e, the sum of individual and investment funds minority shareholder's cash flow rights is substantially different from zero.

Another parameter that is not explicit above, but that probably affects the agency problem analyzed, is the controlling shareholder's voting rights. Doubtless, the controlling shareholder must concentrate a high enough fraction of the voting rights in order to determine the firm's payout policy.

In chapter 4, we will present some descriptive statistics in order to argue that the agency problem is indeed relevant. More specifically, we show that the controlling shareholder is usually a corporation, and that the cash flow rights of minority shareholders who are individuals is substantially different from zero. We also present evidence that the average voting rights of the controlling shareholders is usually bigger than $50 \%$, so that they seem to have enough bargaining power to influence the firm's cash flow distribution policy. 


\section{3 \\ Database and Descriptive Statistics}

\section{1}

\section{Database}

Our initial sample consists of all firms listed on São Paulo Stock exchange (B3 stock exchange) from 1996 to 2017. The sample period is restricted at this time frame because 1996 is the year in which the legislation validated interest on equity as a way of profit distribution by public and private companies, and 2017 is the last year with audited financial statements available. Firm-level accounting data in a yearly frequency was gathered from Economatica platform. Payout data on both interest on equity and dividends were made available by the financial consultancy ComDinheiro. That initial sample consists of 765 firms and 22 years.

From that list of 765 companies, we randomly selected 200 (100 firms from the Novo Mercado and the other 100 from other listing segments) in order to construct an ownership structure database. The ownership structure data is described in prospectuses of securities distribution available at the Brazilian securities and exchange commission (Comissão de Valores Mobiliários in Portuguese) website. Because not all firms make its prospectuses available, we were only able to hand collect 184 prospectuses out of these 200 . This ownership structure database was constructed so that we could identify the ultimate controlling shareholder and in turn justify the model assumption that this usually owns shares from our sample firms through a corporation different from an investment fund. From the total of 184 prospectuses collected, 96 are from firms that did their IPO at the Novo Mercado premium segment, 12 from firms that became public by initially listing their shares at either Nível 1 or Nível 2 premium segments, and the remaining 76 from companies that opened their capital at traditional listing segments.

Because those public prospectuses usually are available at few time periods, we collected the oldest ones available for each company, which means we are only able to observe the ownership structure of each firm at one specific year. By doing so, we are assuming that this ownership structure hasn't changed substantially over time. We rely on the existing stock ownership 
literature that presents evidence on the persistence of large block holders through time to support this assumption (Donelli et al. (2013), Barclay and Holderness (1989), Holderness (2016)).

We are interested at verifying whether firms chose to pay dividends instead of interest on equity because they are maximizing value or because of agency problems. Because we are mainly analysing how a firm chose between interest on equity and dividends to determine its payout policy, we drop all firm year observations with no profit distribution to shareholders. To make sure we are comparing firms eligible to deduct interest on equity payments from the corporate taxes (see chapter 2 to review the eligibility criterion), we only keep in our panel firm year observations with positive book value of equity and either positive earnings before interest on equity and taxes, or positive retained earnings plus earnings reserve.

From the resulting sample of 344 firms, we eliminated firm year observations with effective corporate tax rates below 0 or above 1 , in which we proxied for the effective corporate tax rate as the ratio of paid taxes to profits before taxes. In Brazil, the effective corporate tax rate faced by a company is an unobservable variable. That is so because the observable accounting profit before taxes is subject to inclusions and exclusions in order to be adjusted into the taxable profits which serves as the basis for calculating the income tax owed by the company. ${ }^{1}$ Unfortunately, this adjustment process is done in an accounting book of each company, and because that accounting book is not publicly disclosed, we are not able to observe the taxable profits of our sample firms. For those firms whose profits before taxes were subject to few adjustments before being transformed into taxable profits, the proxied corporate tax rates are closer to the real unobserved ones.

We also truncated at 0 the effective corporate tax rate of those companies that had a negative profit before taxes and an income tax refund because the computed corporate tax rates of those firms were artificially positive. Our final sample consists of an unbalanced panel with 335 firms and 22 years, totaling 3059 observations. To mitigate the effects of outliers, we winsorized all accounting variables as well as the dividends and interest on equity payments at the 1 and 99 percentiles.

Because the sample of 184 firms for which we collected the ownership data is a subset of our initial panel of 765 firms, 137 of these 184 companies survived the aforementioned selection process, which enables us to identify the ownership structure of $41 \%$ of the 335 total companies available in our final

\footnotetext{
${ }^{1}$ Examples of exclusions are research and development expenses and losses from previous years. Inclusions can be fines filled by the IRS and excess of deductible expenses, for example.
} 
panel.

The ownership database function is only to construct descriptive statistics necessary to justify the relevancy of the agency problem, which is done in chapter 4. Because we collected the oldest prospectuses of public distribution for each company, the ownership data is only available at one specific year for each firm, and therefore, we don't use this ownership database in our empirical strategy.

Ideally, we should use this ownership database to identify and exclude firms whose controlling shareholders owns shares of the company via an investment fund from the Regression Discontinuity analysis. Indeed, if the controlling shareholder owns shares via an investment fund, he would probably always be willing to be paid in interest on equity because of the higher tax benefit granted to investment funds (the $15 \%$ tax exemption mentioned on section 2.1).

Our estimates barely changes if we consider these exclusions because we are able to identify just a few companies that satisfy the conditions of being controlled via an investment fund in our database. More precisely, in the final panel, 15 companies are identified as controlled via an investment fund. Because the estimates are practically identical whether we made that sample restriction or not, we decided to present our results on chapter 5 and 6 by considering the full sample. ${ }^{2}$

Now that we described our database, we are going to present some descriptive statistics between the groups of interest on equity payers and only dividend payers.

\section{2}

\section{Descriptive Statistics}

Although Boulton et al. (2012), Carvalho (2012) and Lee-Ness (2001) already documented that many firms forgo the tax benefits of interest on equity by only paying dividends, we graph the percentage of firms eligible to deduct IOE payments from the corporate taxes that only paid dividends against the ones that used interest on equity to distribute profits from 1996 to 2017 on figure B.1. We do so to reinforce that this relatively low adhesion of Brazilian companies to interest on equity, already documented by the existing literature,

${ }^{2}$ Although one could argue that this is an identification issue, the fact that we are considering the full sample only bias against our findings. That might happen because companies controlled via an investment fund would be paying interest on equity at a higher frequency when facing a lower corporate tax rate than 0.228625 then they would if controlled by a corporation, which in turn would reduce the jump in the probability of paying IOE when moving from below to above the 0.228625 cutoff. 
persisted along time. Indeed, according to our graph, by 2017, almost $50 \%$ of the companies that distributed profits did so exclusively on dividends. From that figure, we verify that from 1997 on, the percentage of firms that only paid dividends is usually above $40 \%$ of the companies that distributed profits.

That graph reinforces our idea that those companies are forgoing the tax benefits of interest on equity either because those benefits are outweighed by the Interest on Equity fiscal costs (which would happen when the corporate tax rate faced by the paying company is lower than $\underline{t}_{C}$ ), or because of agency problems (which happens when the corporate tax rate faced by the paying company is higher than $\underline{t}_{C}$, but lower than $\left.\bar{t}_{C}=0.228625\right)$.

In order to analyze which variables are potentially correlated with the probability of paying interest on equity, we run means and medians difference tests between the group of firms that paid interest on equity and the group that only paid dividends. To reinforce these results, we also run a probit regression using as dependent variable the probability of a firm paying IOE, and as independent variables the same ones used in the means and medians difference tests described above. Both the regression and descriptive statistics analysis were based on Boulton et al. (2012). We don't aim at estimating a causal relationship while running this Probit regression. The regression's goal is only a descriptive one, in which we are trying to indicate which variables are potentially correlated with the probability of a firm paying IOE, so that we can use these variables for validation tests of our empirical strategy, which is done in chapter 6 .

From table A.1, we verify that firms that pay interest on equity are greater, as measured by total assets in billions of reais adjusted by inflation and have better growth opportunities according to the average Tobin's Q, which equals the equity market value of a firm divided by its book value of equity. Interest on equity payers are also more profitable, have higher capital expenditures and equity values than dividend payers. The Premium Segments variable is a dummy equal to one if the company is currently listed on a Premium listing Segment (Novo Mercado, Nível 1, Nível 2, Bovespa Mais or Bovespa Mais Nível 2), and zero if listed on an ordinary segment. That variable's mean indicates that interest on equity payers voluntarily seeks better corporate governance practices with a higher frequency than dividend payers. Even though our model predicts that interest on equity payers should face higher corporate tax rates than dividend payers, both the mean and medians of the two groups are not statistically different.

Although leverage and retained earnings don't seem to differ significantly between the two groups according to table A.1, the probit regression (table A.2) 
indicates that leverage is negatively correlated with the probability of paying Interest on Equity, while an increase in retained earnings implies a higher chance of a firm paying IOE. Except for equity, whose marginal effect on the dependent variable is insignificantly different from zero, the other variables corroborates the results presented in table A.1.

Finally, the variable called agency cost is a dummy equal to one if it's not optimal for the controlling shareholder to be paid in interest on equity and zero otherwise. That is, it is equal to one if the corporate tax rate is higher than 0.228625 and zero if it is equal to or less than 0.228625 .

According to our model, we would expect a negative correlation between the dummy Agency Cost and the probability of paying Interest on Equity. Although the Probit estimate is negative, it's both economically and statistically insignificantly different from zero. Because we are proxying for the effective corporate tax rate, our proxy variable is subject to measurement errors. Therefore, under the classical errors-in-variables assumption that the measurement error is uncorrelated with the true unobserved effective corporate tax rate, our estimates of the effect of the agency cost dummy on the probability of paying interest on equity will suffer from attenuation bias, which is a possible explanation for that estimate of low magnitude.

We focus on the Regression Discontinuity Design in order to reduce that attenuation bias. Even though the regression discontinuity estimates are still subject to the attenuation bias, it's probable that this bias will be reduced by the fact that we are considering just a small neighborhood around the 0.2286 cutoff to conduct the estimation. That is so because if the measurement error is uncorrelated with the true effective corporate tax rate, random chance will determine whether the proxy for that variable will be on the opposite side of the cutoff where the true corporate tax rate is.

Besides, even if the true effective corporate tax rates faced by our sample companies were observable, the regression discontinuity design seems to be the best empirical strategy to identify the effect of the agency problem on the payout policy decision. Indeed, if random chance determines whether a firm will face a corporate tax rate marginally above or below the 0.2286 cutoff, firms facing similar tax rates at opposite sides of the 0.2286 cutoff must be comparable in all relevant characteristics, including unobserved ones, that might be correlated with the decision to pay IOE, which permit us to identify the local average treatment effect of interest.

Therefore, beyond reducing the impact of the attenuation bias, the regression discontinuity seems the best empirical strategy available to explore our 0.2286 cutoff in order to deal with endogeneity problems. 


\section{4}

\section{Agency Problem Relevancy}

The proposed agency problem as an answer to the fact that so many firms forego the tax benefits of interest on equity is only relevant if the conditions listed below are valid:

1. The firms must generally have a controlling shareholder. In fact, if the control is $100 \%$ diffused, the agency problem will not exist by definition.

2. As mentioned in section 2.2, the controlling shareholder should own shares of the paying company through a corporation that is not an investment fund in order to face the additional tax burden of $9.25 \%$ on Interest on Equity for the tax asymmetry between the controlling and the minority shareholders could arise.

3. As also mentioned in section 2.2, the voting rights of the controlling shareholder should be high enough so that he can indeed influence the payout policy. Besides, the controlling shareholder's cash flow rights should be smaller than its voting rights. Indeed, separation of ownership and control is what drives agency problems.

4. The total cash flow rights of shareholders who are corporations should not be too close to one. Indeed, if the cash flow rights of a company are fully owned by corporations, there would be no tax asymmetry between minority and controlling shareholders, which means that the agency problem wouldn't arise.

From table A.3 to A.7, we follow La Porta et al. (1998) in order to classify the ultimate controlling shareholder. More specifically, we use the Final Link 10 criterion to determine the ultimate controlling of the votes of our sample firms. In this criterion, a corporation has a controlling shareholder if this shareholder's direct and indirect voting rights sum at least 10 percent. The controlling' direct voting rights is given by its total fraction of voting shares in relation to the number of outstanding voting shares of the firm. While its indirect voting rights is given by the first shareholder's voting rights in the chain by which the controlling shareholder owns shares from the company in 
our sample, provided that every firm in that chain owns at least $10 \%$ of the voting rights of the predecessor firm.

From table A.3 we can see that the firms usually have a controlling shareholder. Just $1.09 \%$ of our sample firms are widely held according to the Final Link 10 criterion. Besides, this companies are accounted for firms listed on the Novo Mercado special segment, in which $2.08 \%$ of the companies are widely held, while no company listed at other segments is widely held. That was expected because it is easier for firms listed on Novo Mercado to be widely held since firms must follow the one share one vote rule in order to list its shares in this segment. Therefore, it seems that Brazilian companies usually have a controlling shareholder under the Final Link 10 criterion.

In table A. 4 we present both the number of times and the frequency by which the controlling shareholder owns shares of the company through a pyramidal structure and, at the same time, the first corporation of the chain by which he exercises control is different from an investment fund. Following La Porta et al. (1998), we say that the controlling exercises control through a pyramidal structure when it owns shares of the sample company via a chain of companies in which at least one of those companies in the chain is a public traded one. The label Pyramid counts the number of times the controlling follows both the previous conditions of structuring his equity holdings through a pyramidal structure and the first company of that pyramid being a corporation. The label Total is the number of times that a specific category exercises control, and the label Percentage is just the ratio of Pyramid to Total, and measures the frequency we are interested on. In table A.5 we do the same as in A.4 except that we split the full sample in firms listed at Novo Mercado and Other Segments. From both tables A.4 and A.5 we can see that the hypothesis used in our model seems reasonable since $73.63 \%$ of the sample companies are controlled via a pyramidal structure in which the first company of the chain is not an investment fund. That percentage doesn't differ significantly between listing segments, with $72.34 \%$ and $75 \%$ of the companies controlled through a pyramidal structure in which the first company in that pyramid is not an investment fund in the Novo Mercado and in the Other Segments, respectively. We conclude that condition 2 seems to hold since most of our sample companies satisfies this condition. Hence, the model hypothesis that the controlling shareholder owns shares of the paying company through a corporation that is not an investment fund seems quite reasonable.

We justify condition 3 on tables A.6 and A.7. In table A.6, we present means and medians of the voting and cash flow rights of the ultimate controlling shareholders for the full sample. The voting rights of the ultimate 
controlling shareholder is equal to the sum of its direct and indirect voting rights, while its cash flow rights is given by the product of the cash flow rights of each firm in the chain by which he structure his equity holdings. It is worth emphasizing that this cash flow rights differs from the cash flow rights parameters of section 2.2. Indeed, the cash flow rights parameters of section 2.2 are from the first company of the chain by which the ultimate controlling structure its equity holdings, which differs from the controlling shareholder cash flow rights. We present descriptive statistics on the controlling shareholder's cash flow rights in order to show that there is separation of ownership and control.

In table A.7 we split our listing segments between firms listed in the Novo Mercado and firms listed on Other Segments and present only the means of both cash flow and voting rights to save space. From these tables we can confirm that the voting rights of the controlling shareholders are substantial. Even further, the voting rights are substantially greater than the cash flow rights. As a matter of fact, the mean and median voting rights for the full sample are of nearly $60 \%$, against a mean and median cash flow rights of $33.46 \%$ and $23.50 \%$, respectively. By analysing table A.7 we can see that the controlling of the firms listed at Other Segments have higher voting rights than the controlling of companies listed in the Novo Mercado. That seems natural because firms listed on Other Segments are not required to comply with the one share one vote rule, which enables the controlling shareholders to appropriate a larger fraction of the voting rights. Regardless of the listing segments, the controlling usually has a high enough fraction of the voting rights to determine the payout distribution policy. Even further, separation of ownership and control seems to hold.

Finally, in order to justify that condition 4 holds, we present descriptive statistics of the cash flow rights of individuals as well as the cash flow rights of the first companies of the chain by which Corporation and Investment Fund shareholders structure its equity holdings. In table A.8 we present evidence that the cash flow rights of the minority shareholders that are individuals (parameter $(1-\alpha-\beta)$ ) is substantially different from zero, with a mean value of $25.58 \%$ and a median value of $26 \%$ for the full sample. Also, the cash flow rights of minority shareholders who are individuals is much higher for firms listed on Novo Mercado than in Other Segments.

However, Investment Fund minority shareholder's cash flow rights (parameter $\beta$ ) are close to zero. That is justified because when the firm has an investment fund as shareholder, it usually has a large enough share of its stocks, which makes it unlikely for these investment funds to be minority sharehold- 
ers. Indeed, just one company listed at Novo Mercado has Investment Funds as minority shareholders, whose average cash flow rights are of $3.19 \%$. Therefore, the fact that the other companies do not have investment funds as minority shareholders drives the average cash flow right of the full sample to $0.268 \%$.

Even though there are not many investment fund minority shareholders, there still exists a taxation asymmetry between the controlling shareholder and the minority shareholders who are individuals. Therefore, the fact that the shareholders who are individuals have a substantial stake on the firm's cash flow rights, as presented on table A.8, is enough to justify the relevancy of the agency problem.

From table A.9 we can see that the total cash flow rights of corporations that are not investment funds is not close to one. It has an average value of $44.11 \%$ and a median value of $45.80 \%$ in the full sample. In the Novo Mercado segment, corporations have a lower cash flow rights when compared to the corporations listed on Other Segments.

Because the four conditions mentioned above seems to hold irrespective of the listing segments, we conclude that the Brazilian companies faces the incentives necessary to induce the agency problem in the payout policy as described in section 2.2 . 


\section{5 \\ Empirical Strategy, Results and Robustness Checks}

\section{1 \\ Empirical Strategy}

Our goal is to verify whether the tax asymmetry on interest on equity revenues between shareholders might induce firms to agency problems in determining the payout policy, i.e, in the decision of paying dividends or interest on equity. In order to do so, we apply a Sharp Regression Discontinuity Design to estimate the Local Average Treatment effect (LATE) of a firm facing a situation in which it is optimal for both controlling and minority shareholders to be paid in Interest on Equity. Our dependent variable is a dummy equal to one if the firm paid Interest on Equity in a given year, which we loosely denote as the probability of a firm paying Interest on Equity from now on. The running variable is the corporate tax rate faced by the paying company, and the threshold chosen to evaluate the discontinuity is the $22.86 \%$ upper bound of the tax rate interval in which the agency problem is induced. The treatment status is whether it is optimal for both the controlling and minority shareholders to be paid in IOE. The sharp design is justified for the treatment status is a deterministic function of the running variable.

Our model (see section 2.2) justifies the regression discontinuity design as the empirical strategy because the upper bound $\left(\bar{t}_{C}=0.228625\right)$ of the corporate tax rate interval that induces the agency problem provides a natural cutoff to split the firms between treatment and control groups. Indeed, an empirical implication of our model is that firms facing a corporate tax rate marginally above 0.228625 should pay more interest on equity than those facing a tax rate marginally below 0.228625 . That is so because even though it would be optimal for firms facing a corporate tax rate marginally below 0.228625 to distribute cash in IOE, that is not optimal for the controlling shareholder. For those firms facing a tax rate above 0.288625 , on the other hand, it is optimal for both the firm's shareholders as whole, as for the controlling shareholder to be paid in IOE.

Thus, if we verify an increase in the probability of a firm paying interest on equity when its corporate tax rate is marginally above $22.8625 \%$ in 
comparison to the probability of paying IOE when the tax rate is marginally below $22.8625 \%$, we would be providing evidence of the agency problem. Indeed, we can explain that increase in the probability of paying IOE for firms facing tax rates marginally above 0.228625 in comparison to those facing tax rates marginally below that cutoff as the controlling shareholder's influence on determining the distribution of profits in dividends when the corporate tax rate is marginally below 0.2286 , and the distribution in interest on equity when the corporate tax rate is marginally above 0.2286 .

More specifically, we will be estimating the following equation:

$$
I O E_{i t}=\delta+\beta T_{C i t}+\rho D_{i t}+\epsilon_{i t}
$$

In which $\epsilon_{i t}$ is an error term with zero expected value conditional on the independent variables, $T_{C i t}$ is the effective corporate tax rate faced by firm i at year $\mathrm{t}$ and $D_{i t}=\mathbb{1}\left(T_{C i t} \geq 0.228625\right)$, that is, $D_{i t}$ is a dummy variable indicating whether firm i was assigned to treatment at year t, i.e, if it was optimal for both its controlling and minority shareholders to be paid in interest on equity instead of dividends. Our dependent (or outcome) variable, $I O E_{i t}$ is a dummy variable equal to 1 if firm i paid cash in interest on equity at year t, which means it only distributed cash via interest on equity, or both in interest on equity and dividends, and it is equal to zero if the firm only distributed profits via dividends to its shareholders. Our parameter of interest is $\rho$, which measures the causal effect of the treatment at the discontinuity point, and it is the same as the difference in the probability of a firm paying interest on equity when it is assigned to treatment from the probability of paying IOE when it is assigned to control.

Indeed, let us denote by $I O E 1_{i t}$ the outcome variable of firms submitted to treatment,i.e, those firms in which it would be optimal for both controlling and minority shareholders to be paid in interest on equity. Also, we denote by $I O E 0_{i t}$ the outcome variable of those firms in the control group,i.e, those in which it would be optimal for all the firm's shareholders to be paid in IOE except for the controlling one, who would be better off being paid on dividends. Therefore, we can write the dependent variable as:

$$
I O E_{i t}=I O E 1_{i t} D_{i t}+I O E 0_{i t}\left(1-D_{i t}\right)= \begin{cases}I O E 1_{i t}, & \text { if } T_{C i t} \geq 0.228625 \\ I O E 0_{i t}, & \text { if } T_{C i t}<0.228625\end{cases}
$$


Our identification hypothesis is that the regression function of $I O E_{i t}$ on $T_{C i t}, \mathbf{E}\left[I O E_{i t} \mid T_{C i t}\right]$, is a continuous function at the cutoff value of $22.8625 \%$. Besides, this function differs depending whether the firm is assigned to treatment or to control, that is it, $\mathbf{E}\left[I O E 1_{i t} \mid T_{C i t}\right]$ differs from $\mathbf{E}\left[I O E 0_{i t} \mid T_{C i t}\right]$. In practical terms, this hypothesis means that units that face very similar corporate tax rates on opposite sides of the cutoff are comparable in all relevant aspects, except for their treatment status. Under this hypothesis, we are able to identify the local average treatment effect at the 0.228625 cutoff value of a firm facing a situation in which it is optimal for both controlling and minority shareholders to be paid in IOE:

$$
\rho=\mathbf{E}\left[I O E 1_{i t}-I O E 0_{i t} \mid T_{C i t}=0.228625\right]
$$

Indeed, under equation (5-2) and the continuity hypothesis of $\mathbf{E}\left[I O E_{i t} \mid T_{C i t}=0.228625\right]$, one can verify that the right hand side of equation (5-3) is the same as the right hand side of equation (5-4), described below.

$$
\rho=\lim _{t_{C i t} \rightarrow 0.228625^{+}} \mathbf{E}\left[I O E_{i t} \mid T_{C i t}=t_{C i t}\right]-\lim _{t_{C i t} \rightarrow 0.228625^{-}} \mathbf{E}\left[I O E_{i t} \mid T_{C i t}=t_{C i t}\right]
$$

Therefore, we are able to estimate the parameter $\rho$ provided that we estimate the right hand side of equation (5-4). Which is done by estimating one regression function at a small neighborhood to the right of the cutoff value and another regression within a small neighborhood to the left of the cutoff value, and computing the difference of these two estimated regressions.

We follow Mattias D. Cattaneo (2018), Imbens and Lemieux (2008) and Lee and Lemieux (2010) by implementing a local linear regression on both sides of the 0.228625 cutoff in order to estimate the parameter $\rho$. More specifically, this procedure consists on applying a weighted least squares of $I O E_{i t}$ on $T_{C i t}$ using only observations between $0.228625-h$ and $0.228625+h$, in which $h>0$ is the bandwidth that determines the neighborhood around the cutoff value where the estimation is conducted. The weights are determined by a kernel function $\mathrm{K}($.$) , and observations closer to the cutoff value of 0.228625$ receive more weight than those further away.

One of the distinguishing features of this approach is that it doesn't rely on assumptions about the true parametric form of the regression function. In fact, the weighting scheme formally consists on a non-parametric approximation to the unknown underlying regression function within the neighborhood 
determined by the bandwidth. Analytically, our estimate of the local average treatment effect, $\hat{\rho}$, is given by the difference $\hat{\rho}=\hat{\rho}_{r}-\hat{\rho}_{l}$, where $\hat{\rho}_{r}$ and $\hat{\rho}_{l}$ are the intercept parameters of the estimated regressions to the right and to the left of the 0.228625 cutoff, respectively. That is, they are the first components of the vectors $\left(\hat{\rho_{l}}, \hat{\beta_{l}}\right)$ and $\left(\hat{\rho_{r}}, \hat{\beta_{r}}\right)$ that solve for the following problems:

$\min _{\left(\rho_{l} \beta_{l}\right)} \sum_{i t \mid 0.228625-h<T_{C i t}<0.228625}^{N} K\left(\frac{T_{C i t}-0.228625}{h}\right)\left(I O E_{i t}-\rho_{l}-\beta_{l}\left(T_{C i t}-0.228625\right)\right)^{2}$

$\min _{\left(\rho_{r} \beta_{r}\right)} \sum_{i t \mid 0.228625 \leq T_{C i t}<0.228625+h}^{N} K\left(\frac{T_{C i t}-0.228625}{h}\right)\left(I O E_{i t}-\rho_{r}-\beta_{r}\left(T_{C i t}-0.228625\right)\right)^{2}$

Our choices of Kernel and bandwidth follow the RD literature (Lee and Lemieux (2010), Mattias D. Cattaneo (2018)). We implement the bandwidth that minimizes the Mean Squared error (MSE) of the point estimator $\hat{\rho}$, and the triangular Kernel, $K(u)=(1-|u|) \mathbb{1}(|u| \leq 1)$, because it leads to a point estimator with optimal properties in a MSE sense when combined with the bandwidth that minimizes the MSE. For robustness checks, we also present our estimates with the uniform and epanechnikov kernels.

Some Regression discontinuity applications used to approximate the regression functions by higher order polynomials (or global polynomial) of the running variable. However, as emphasized by Mattias D. Cattaneo (2018), it's now widely recognized by the existing literature that the higher polynomial approach has undesirable properties in terms of point estimation and statistical inference. Mattias D. Cattaneo (2018) argues that a global polynomial delivers a poor approximation at boundary points besides heavily influencing the point estimation by observations far away from the boundary. In contrast, the linear approximation has better theoretical properties at boundary points and is less sensitive to outliers. Since the estimation is conducted on a small neighborhood of the cutoff, which is essentially a boundary point, we focus on the linear approach to present our main results, and use higher order polynomials for robustness checks.

Mattias D. Cattaneo (2018) argues that although the global polynomial approach delivers poor approximations at boundary points, it usually deliver a good approximation of the true regression function over the full support of the running variable. Therefore, following the RD applied works methodology, we begin with a graphical analysis in order to verify the existence of a discontinuity 
in the regression function of $I O E_{i t}$ on $T_{i t}$ at the 0.228625 cutoff value, in which the estimated regression function plotted is a fourth order degree polynomial of the running variable.

It's important to emphasize that this is not the estimated discontinuity. Indeed, the graphical analysis presents the discontinuity at the proposed cutoff using the full support of the running variable by estimating a high order polynomial of the regression function. On the other hand, the local average treatment effect is locally estimated by a linear approximation of the regression. The graphical analysis is just a way of visualizing the identification strategy.

We present the conventional, the bias-corrected and robust methods of estimation and inference. The conventional one assumes that the local regression function assumes the exact non-parametric form used in the approximation and constructs standard errors and confidence intervals in the same way as done in parametric least squares applications. Because the linear polynomial approximation is non-parametric, the estimated treatment effect is biased and the bias-corrected approach removes the estimated bias term from the point estimation and constructs confidence intervals centered at the bias corrected point estimate. Finally, the robust approach, which is considered the superior one, incorporates the bias correction step and improves the bias correction approach by estimating standard errors that account for the extra variability introduced in the bias estimation step. Now that the methodology has been clarified we proceed to the results.

\section{2 Results}

We can see from figure B.2 that it seems to be a discontinuity in the probability of paying Interest on Equity at the 0.228625 threshold for the full sample. ${ }^{1}$ However, from table A.10, we can see that the local estimated discontinuity of nearly $5 \%$ lacks statistical significance regardless of the method used. Before concluding that the agency problem doesn't seem relevant, we should verify whether it persists in firms with different practices of corporate governance. Indeed, Brazilian public companies have the option to list its shares on Premium Segments (The Premium Segments are Novo Mercado, Nível 1, Nível 2, Bovespa Mais and Bovespa Mais Nível 2) provided that they

\footnotetext{
${ }^{1}$ According to figure B.2, we can see that some firms have very high income tax rates, although the maximum marginal rate in Brazil is $34 \%$ for non-financial corporations and $45 \%$ for financial firms. However, firms fined by the Internal Revenue Service or that have accounted for excess expenses deductible from the Income Tax must readjust those expenses in such a way that they end up paying an effective rate higher than the maximum marginal rate.
} 
conform with stronger practices of corporate governance (see de Carvalho and Pennacchi (2012) for details on the required practices of corporate governance by the Premium Segments). Hence, we expect that the agency problem should be more likely in those firms that doesn't voluntarily commit to better practices of corporate governance by listing its shares on ordinary segments.

To verify our conjecture, we also plot the estimated probability of paying IOE against the corporate tax rates for firms listed at ordinary segments in figure B.3, which displays a meaningful discontinuity at the 0.228625 cutoff value. Confirming the graphical analysis, we can see from table A.11 that the local average treatment effect estimates are positive and statistically significant. Actually, the conventional estimated treatment effect is higher than $20 \%$, while both the bias corrected and the robust ones are nearly of $24 \%$. Irrespective of the applied method, the estimates are statistically significant at least at a $5 \%$ level. The interpretation of our estimates is that firms listed at ordinary segments facing a corporate tax rate marginally above $22.8625 \%$ are at least $20 \%$ more likely to pay interest on equity to its shareholders than those firms also listed at ordinary segments but facing a corporate tax rate marginally below $22.8625 \%$.

For companies listed at premium segments, we can see from figure B.4 that there is no discontinuity on the estimated regression function at the cutoff value of 0.228625 . Even further, table A.12 shows that the estimated average treatment effect for the firms listed at premium segments is negative and is not statistically different from zero regardless of the applied method.

We conclude that the agency problem is meaningful precisely for those companies that adopt poorest practices of corporate governance, while it seems irrelevant for those that voluntarily commit to strong governance and disclosure standards by listing its shares at premium segments.

In order to show the impact of the loss in the firm value as a consequence of the controlling shareholder influencing an payout policy that doesn't minimize total taxes, we present the average estimate of the agency cost. Our estimate of the average agency cost incurred by those companies that only pay dividends is of $\mathrm{R} \$ 29,629,210.00$.

\section{3 \\ Robustness Checks}

We finalize this chapter with two robustness checks of our results presented on table A.11. In the first test we run local linear regressions using different kernels. In the second one, we estimate the local average treatment 
effect of interest by implementing local polynomials of higher orders to approximate for the true regression function. As mentioned in section 5.1, the linear approximation has better MSE properties and is less sensitive to outliers. However, providing evidence that the statistical significance of our estimates are not too sensible to the polynomial degree is a way of reinforcing our findings. To save space, we just present the robust estimates for both tests. ${ }^{2}$ In table A.13 we present our estimates of the increase in the probability of paying IOE for firms listed in ordinary segments by using kernels different from the triangular. The second column presents the results using a uniform kernel $(K(u)=\mathbb{1}(|u| \leq 1))$, and the third column using a epanechnikov kernel $\left(K(u)=\left(1-u^{2}\right) \mathbb{1}(|u| \leq 1)\right)$. Both estimates differs slightly from the one that uses the triangular kernel. The robust estimate based on the uniform kernel is of $26.171 \%$, and the one based on the epanechnikov is equal to $23.93 \%$. They are also statistically different from zero at a $5 \%$ level.

In table A.14 we run the same model as in A.11 except that now we allow for different polynomial degrees to approximate for the regression function. The second, third and fourth columns of table A.14 presents the results using second, third and fourth degree polynomials, respectively. To save space, we only present our results using the triangular kernel, since this kernel has better MSE properties when combined with the optimal MSE bandwidth. ${ }^{3}$ Our second degree polynomial robust estimate of the increase in the probability of paying IOE is equal to $29.431 \%$, with a $\mathrm{P}$-value of $2.6 \%$. The robust estimates based on the third and fourth polynomials are of $31.329 \%$ and $33.947 \%$, with P-values of $5.3 \%$ and $4.6 \%$, respectively.

We conclude that our estimate of the increase in the probability of a firm paying IOE when it is optimal for its controlling shareholder to be paid in IOE is not driven by a specific kernel or polynomial used to approximate the regression function on the neighborhood of the cutoff, which strengthens our confidence that our results are driven by an agency problem in the payout policy of Brazilian companies listed at ordinary segments.

Notice that the interval's lower bound, $\underline{t}_{C}$, could also be used to test our model. That is so because, provided that the corporate tax rate is within the interval $\left[\underline{t}_{C} ; \bar{t}_{C}\right]$ it is optimal for the company to distribute profits in IOE although the controlling shareholder would be better off being paid in dividends. If the corporate tax rate is below that lower bound, on the other

\footnotetext{
${ }^{2}$ In unreported tests, we checked that the estimates are positive and statistically significant at conventional levels independent of the method used (conventional or bias-corrected).

${ }^{3}$ In unreported tests, we show that the estimates remain statistically different from zero at conventional significance levels regardless of the polynomial degree (second, third our fourth) and of the kernel type (uniform or epanechnikov).
} 
hand, it is optimal for the company to distribute cash in dividends. We conclude that, if we are not able to observe an increase in the probability of paying IOE for companies facing taxes marginally above $\underline{t}_{C}$ in comparison to those facing taxes marginally below $\underline{t}_{C}$, that would probably be justified for the controlling's influence on determining the payout policy on dividends when the corporate tax rate is marginally above $\underline{t}_{C}$.

Although doing this additional test would be useful to reinforce our findings, we can't use the interval's lower bound $\left(\underline{t}_{C}\right)$ to test our model because it varies between firms. Indeed, $\underline{t}_{C}$ depends on both the total cash flow rights of shareholders who are corporations $(\alpha)$ as well as the minority shareholders investment fund's cash flow rights $(\beta)$, which are both firm specific. 


\section{6}

\section{Validation of the Regression Discontinuity Design}

Our identification hypothesis is that the regression function of the outcome on the running variable (or score) is continuous at the 0.228625 cutoff, which basically means that units that receive similar values of the forcing variable on both sides of the cutoff are analogous to each other in all relevant aspects, except for their treatment status. Although that hypothesis is also about unobservable features and therefore inherently untestable, it is possible to conduct some falsification tests to provide evidence of the plausibility of this assumption. Since we provided evidence that the treatment status affects the outcome variable only for those firms listed at ordinary segments, we conduct these falsification tests only for the sample of firms listed at these segments.

We follow the Regression Discontinuity literature and implement three empirical validation tests:

1. Null treatment effect on variables that shouldn't be affected by the treatment status, but that are correlated with our outcome variable

2. Null treatment effect on predetermined variables.

3. Continuity of the running variable (score) density around the cutoff

The first test goal is to check whether, near the cutoff, treated units are similar to control units in terms of observable characteristics that might affect the dependent variable, but that shouldn't be affected by the treatment. Indeed, if treatment and control units differs substantially on some of these variables, it might be the case that some unobservable variable in the error term might be driving our results. We implement this test in a similar way we did to estimate our treatment effect in chapter 5 , i.e, we begin with a graphical analysis to investigate whether it seems to be a discontinuity of each variable at the 0.228625 cutoff, and use the local linear regression with the triangular kernel and the optimal mean squared error bandwidth to estimate the potential discontinuity.

The variables used to conduct this first test are those used on both the means and medians tests (table A.1) and in the probit regression (table 
A.2). More specifically, we test whether the regression functions of Assets, Tobin's Q, Leverage, Capex, Profitability, Retained Earnings and Equity are discontinuous at the 0.228625 cutoff level. ${ }^{1}$ Actually, the Probit regression and the means and medians tests indicates that those variables are correlated with the probability of paying interest on equity. Besides, there is no theoretical reason why these variables should be affected by the treatment status.

From figures B.5 to B.11 we plot the estimated regression function of each variable on the corporate tax rate and verify whether there is a discontinuity at the 0.228625 cutoff value. Both Profitability and Capex regression functions seems to be discontinuous at the 0.228625 cutoff. However, that graphical evidence doesn't hold formally. We present the local linear regression robust estimates on table A.15, which shows that for any of the variables the estimated discontinuities are not statistically different from zero at conventional significance levels.

The idea of the second test is that a variable determined prior to the assignment of the treatment status shouldn't be affected by the current treatment status. We choose the first lag of our dependent variable as such a predetermined variable. Indeed, the current corporate tax rate should only affect the current probability of paying interest on equity, not the former period probability of paying interest on equity. Therefore, providing evidence that the first lag of the outcome variable is unaffected by the treatment status even though this variable is highly correlated with the current value of the outcome variable (correlation of 0.7712 ) is a way of reinforcing the validity of our regression discontinuity design.

The preliminary graphical analysis, presented on figure B.12, indicates a potential discontinuity of the regression function of the first lag ot the outcome variable at the 0.228625 cutoff. However, the estimates of the sharp regressions of the first lag of the outcome variable on the corporate tax rate, presented on table A.16, disconfirms that preliminary evidence. To save space, we only show the robust estimate, which is considered the superior one, for three different types of kernels (triangular, uniform and epanechnikov) to reinforce our findings. None of the three estimates is statistically different from zero.

Finally, if the rule that determines the treatment status is of common knowledge, firms can manipulate the corporate tax rate in order to be assigned to treatment if they are in the control group, or the other way around. If the firms that manipulate the running variable in order to change its treatment status significantly differs from the ones that doesn't, our estimates of the

${ }^{1}$ We normalize both Assets and Equity by its logarithms, which is the same as done in table A.2 
local average treatment effect will be biased. In the absence of manipulation, we should expect that the number of treated units just above the 0.228625 cutoff shouldn't differ too much from the number of control units just below it. In other words, if random chance determines which units are just below or just above the 0.228625 cutoff value, we would observe a continuous probability density function of the score around the cutoff.

To test for that continuity of the score's (corporate tax rate) density around the 0.228625 value, we implement the McCrary test (see McCrary (2008)). The test's null hypothesis is that the score's density function is continuous at 0.228625 . Hence, if we are able to reject the null hypothesis, we will be providing evidence that the firms might be manipulating their corporate tax rates. Table A.17 presents the discontinuity estimates of the score's density function at 0.228625 and its P-values for a second order and a linear local estimation. The second and first order estimate's P-values are of $62.70 \%$ and $70.89 \%$, respectively. Therefore, we cannot reject the null hypothesis of continuity of the score's density at the cutoff, which is evidence that manipulation of the corporate tax rate doesn't seem like a major concern. To provide a graphical analysis of the McCrary test, we plot both the histogram and the estimated density function of the corporate tax rate in figures B.13 and B.14, respectively.

From the results of the three conducted falsification tests, we can verify that the control and treatment groups are similar in observable aspects that might affect the outcome variable and that it doesn't seem to be the case that other variables might be driving the decision of a company to pay IOE or dividends in a neighborhood around the 0.228625 cutoff value. These results reinforces our interpretation that the estimates presented in table A.11 are driven by the firm's treatment status, i.e, the observed increase in the probability of paying IOE for those companies facing a corporate tax rate marginally above 0.228625 relative to those facing a tax rate marginally below that cutoff are explained by an agency problem between the controlling and minority shareholders of companies listed on ordinary segments. 


\section{Conclusions}

In this dissertation, we contribute to the existing literature by providing evidence that asymmetric taxation rules between a firm's shareholders can lead to agency problems on corporate financing strategies. By doing so, we show that the conflicts of interest pointed out by Myers and Majluf (1984) are also present in the adoption of tax saving schemes. We explored the Brazilian tax Law, which allows public and private companies to distribute cash in both interest on equity as well as in dividends to present such an evidence. Even though paying interest on equity might maximize the total net tax value distributed, it might not be beneficial for the controlling shareholder to be paid in interest on equity depending on the paying firm's tax bracket. Indeed, many Brazilian companies only pay dividends to its shareholders (see figure B.1).

These conflicts of interest arises because the controlling shareholders usually structure its equity holdings via a pyramid, which makes them to face a higher tax burden on interest on equity revenues. More specifically, we show that it is tax advantageous for the controlling shareholder to be paid in interest on equity only if the effective corporate tax rate faced by the paying company is higher than $22.8625 \%$. Hence, if the paying company is facing a corporate tax rate lower than $22.8625 \%$, the controlling shareholder could be using its voting rights to determine a payout policy exclusively on dividends, even if the minority shareholders would be better off being paid in interest on equity. In that situation, the firm would incur in a loss of the total value distributed, that is, it would be incurring an agency cost.

By applying a sharp regression discontinuity design, we show that there is an increase of at least $20 \%$ in the probability of paying interest on equity for those companies facing a corporate tax rate marginally above $22.8625 \%$ in comparison to those facing a tax rate marginally below that cutoff. That increase only exists for companies listed at ordinary segments. There is no such increase for companies listed in premium segments.

Notice how the low adhesion of Interest on Equity by Brazilian companies resembles the abandonment of stock repurchases by many companies in the USA despite these payout instruments fiscal advantages (see Bagwell and 
Shoven (1989)). Indeed, both interest on equity and stock repurchases revenues are taxed differently between shareholders, which makes the tax minimization problem of the firm differ from the controlling shareholder's.

From the aforementioned example, we can illustrate how this dissertation provides a framework for identifying firms subject to agency problems in the adoption of any tax strategies in which the tax burden of the strategy varies between shareholders. 


\section{Bibliography}

Allen, F., Bernardo, A. E., and Welch, I. (2000). A theory of dividends based on tax clienteles. Journal of Finance, 55(6):2499-2536.

Bagwell, L. S. and Shoven, J. B. (1989). Cash distributions to shareholders. Journal of Economic Perspectives, 3(3):129-40.

Barclay, M. J. and Holderness, C. G. (1989). Private benefits from control of public corporations. Journal of Financial Economics, 25(2):371-395.

Bonomo, Marco., M. L. D. M. J. M. (2015). Short-selling restrictions and returns: a natural experiment. Working Paper.

Boulton, T. J., V., Braga-Alves, M., and Shastri, K. (2012). Payout policy in brazil: Dividends versus interest on equity. Journal of Corporate Finance, 18(4):968979 .

Carvalho, S. L. (2012). Incerteza jurídica: prejudicial para todas as firmas, porém mais ainda para as menores. Unpublished Master's thesis from PUC-Rio.

de Carvalho, A. G. and Pennacchi, G. G. (2012). Can a stock exchange improve corporate behavior? evidence from firms' migration to premium listings in brazil. Journal of Corporate Finance, 18(4):883-903.

Desai, M. A., Dyck, A., and Zingales, L. (2007). Theft and taxes. Journal of Financial Economics, 84(3):591-623.

Donelli, M., Larrain, B., and Francisco Urzúa, I. (2013). Ownership dynamics with large shareholders: An empirical analysis. Journal of Financial and Quantitative Analysis, 48(02):579-609.

Holderness, C. G. (2016). Law and ownership reexamined. Critical Finance Review, 5(1):41-83.

Imbens, G. and Lemieux, T. (2008). Regression discontinuity designs: A guide to practice. Journal of Econometrics, 142(2):615-635.

La Porta, R., de Silane, F. L., and Shleifer, A. (1998). Corporate ownership around the world. NBER Working Papers 6625, National Bureau of Economic Research, Inc. 
Lee, D. S. and Lemieux, T. (2010). Regression discontinuity designs in economics. Journal of Economic Literature, 48(2):281-355.

Lee-Ness, W., Z. J. (2001). Interest on equity versus the tax advantage of debt. Revista de Administração, 36(2):89-102.

Martins, T. C. and Novaes, W. (2012). Mandatory dividend rules: Do they make it harder for firms to invest? Journal of Corporate Finance, 18(4):953-967.

Mattias D. Cattaneo, Nicolás Idrobo, R. T. (2018). A practical introduction to regression discontinuity designs: Volume i. Monograph prepared for Cambridge Elements: Quantitative and Computational Methods for Social Science.

McCrary, J. (2008). Manipulation of the running variable in the regression discontinuity design: A density test. Journal of Econometrics, 142(2):698-714.

Miller, M. (1977). Debt and taxes. Journal of Finance, 32(2):261-75.

Myers, S. C. and Majluf, N. S. (1984). Corporate financing and investment decisions when firms have information that investors do not have. Journal of Financial Economics, 13(2):187-221. 


\section{Tables}

Table A.1: Characteristics between Interest on Equity and Dividend payers

\begin{tabular}{|c|c|c|c|c|c|c|}
\hline & \multirow{2}{*}{$\begin{array}{l}\text { Interest } \\
\text { Mean }\end{array}$} & \multirow{2}{*}{$\begin{array}{c}\text { on Equity Payers } \\
\text { Median }\end{array}$} & \multicolumn{2}{|c|}{ Dividend Payers } & \multicolumn{2}{|c|}{ Difference } \\
\hline & & & Mean & Median & Mean & Median \\
\hline Assets & 22,50 & 3,47 & 9,20 & 2,82 & $13,30284^{* * *}$ & $0,658766^{*}$ \\
\hline Tobin's Q & 1,53 & 1,20 & 1,29 & 1,03 & $0,240583^{* * *}$ & $0,169818^{* * *}$ \\
\hline Leverage & 0,23 & 0,22 & 0,24 & 0,23 & $-0,0051367$ & $-0,0071620$ \\
\hline Capex & 0,07 & 0,06 & 0,06 & 0,04 & $0,0101695^{* * *}$ & $0,014996^{* * *}$ \\
\hline Profitability & 0,11 & 0,10 & 0,09 & 0,07 & $0,019922^{* * *}$ & $0,0264397 * * *$ \\
\hline Retained Earnings & 0,14 & 0,11 & 0,13 & 0,11 & $0,0079418^{*}$ & 0,0026253 \\
\hline Equit*- & 6,60 & 1,08 & 2,17 & 0,62 & $4,436492^{* * *}$ & $0,4572095^{* * *}$ \\
\hline Prer $_{\varangle}$ a Segments & 0,54 & & 0,43 & & $0,1059474^{* * *}$ & \\
\hline Corp & 0,24 & 0,25 & 0,23 & 0,24 & 0,0076715 & 0,0098501 \\
\hline
\end{tabular}

Note: We present means and medians difference tests of variables between interest on equity payers and dividend payers. Assets is total assets adjusted by inflation in billions of reais. Tobin's $Q$ is equal to the ratio of the firms market value of equity to its book value of equity. Leverage is the ratio of total debt to total assets. Capex is the ratio of capital expenditure to total assets. Profitability is the ratio of earnings before interest and taxes to total assets. Retained earnings is the ratio of retained earnings plus earnings reserves to total assets. Equity is book value of equity adjusted by inflation in billions of reais. Premium Segments is a dummy variable equal to 1 if the firm has its shares listed at a B3 exchange Premium Segment, and 0 otherwise. Corporate tax rate is the ratio of taxes paid to total earnings before taxes. ${ }^{* * *} \mathrm{P}$-value $<0.01,{ }^{* *} \mathrm{P}$-value $<0.05,{ }^{*} \mathrm{P}$-value $<0.1$. 
Table A.2: Probit Regression

\begin{tabular}{lcc}
\hline Dependent Variable: Probability of Paying IOE \\
\hline Assets & $0.283^{* * *}$ & $0.276^{* * *}$ \\
& $(0.103)$ & $(0.105)$ \\
Tobin's Q & $0.188^{* * *}$ & $0.189^{* * *}$ \\
& $(0.0540)$ & $(0.0540)$ \\
Leverage & $-1.084^{* * *}$ & $-1.080^{* * *}$ \\
& $(0.269)$ & $(0.269)$ \\
Capex & $1.273^{* *}$ & $1.258^{* *}$ \\
& $(0.589)$ & $(0.590)$ \\
Profitability & $1.264^{* *}$ & $1.249^{* *}$ \\
& $(0.591)$ & $(0.593)$ \\
Retained Earnings & $1.543^{* * *}$ & $1.550^{* * *}$ \\
& $(0.392)$ & $(0.392)$ \\
Equity & -0.142 & -0.134 \\
& $(0.106)$ & $(0.108)$ \\
Premium Segments & $0.192^{* *}$ & $0.191^{* *}$ \\
& $(0.0810)$ & $(0.0810)$ \\
Agency Cost Dummy & & -0.0283 \\
& & $(0.0724)$ \\
Pseudo R & & $7.92 \%$ \\
Observations & $7.92 \%$ & 1,436
\end{tabular}

Note: We present the estimates of two Probit regressions of a dummy variable equal to 1 if the company paid interest on equity in a given year and zero if it just paid dividends on the variables described on the first column. Assets is the logarithm of total assets adjusted by inflation in billions of reais. Tobin's Q is equal to the ratio of the firms market value of equity to its book value of equity. Leverage is the ratio of total debt to total assets. Capex is the ratio of capital expenditure to total assets. Profitability is the ratio of earnings before interest and taxes to total assets. Retained earnings is the ratio of retained earnings plus earnings reserves to total assets. Equity is the logarithm of book value of equity adjusted by inflation in billions of reais. Premium Segments is a dummy variable equal to 1 if the firm has its shares listed at a B3 exchange Premium Segment, and 0 otherwise. Agency Cost Dummy is a dummy variable equal to 1 if the corporate tax rate is smaller than 0.228625 and zero otherwise. Time fixed effects are included in both probit regressions presented. The standard errors are displayed in parenthesis. *** $\mathrm{P}$-value $<0.01$, ** $\mathrm{P}$-value $<0.05,{ }^{*} \mathrm{P}$-value $<0.1$. 
Table A.3: Control of publicly traded firms at the moment of the oldest available public distribution of securities by listing segments.

\begin{tabular}{ccccccc}
\hline Classification & \multicolumn{2}{c}{ Novo Mercado } & Other Segments & Full Sample \\
\hline Widely Held & 2 & $2,08 \%$ & 0 & $0,00 \%$ & 2 & $1,09 \%$ \\
State & 3 & $3,13 \%$ & 7 & $7,95 \%$ & 10 & $5,43 \%$ \\
Family & 47 & $48,96 \%$ & 43 & $48,86 \%$ & 90 & $48,91 \%$ \\
Financial Institution & 8 & $8,33 \%$ & 6 & $6,82 \%$ & 14 & $7,61 \%$ \\
Corporation & 14 & $14,58 \%$ & 17 & $19,32 \%$ & 31 & $16,85 \%$ \\
Miscellaneous & 22 & $22,92 \%$ & 15 & $17,05 \%$ & 37 & $20,11 \%$ \\
Total & 96 & $100,00 \%$ & 88 & $100,00 \%$ & 184 & $100,00 \%$ \\
\hline
\end{tabular}

Note: We follow La Porta et al. (1998) in order to classify the ultimate controlling shareholders of our sample firms by using the Final Link 10 criterion. A firm is Widely Held when it does not have a controlling shareholder. The ultimate controlling is the State when the firm is state-owned, which happens when the Federal Government or any company controlled by it is its controlling shareholders. We say that a firm is controlled by a Family when a group of members of the board of administration or directors are the ultimate controlling shareholders. The firm is controlled by a Financial Institution if its ultimate controlling is a Commercial Bank, an Investment Bank or an insurer. If the ultimate controlling is a corporation, that is not a financial institution, then it is classified as a Corporation. Finally, the Miscellaneous classification is designated for firms whose ultimate controlling shareholder is a holding company with more than one controlling shareholder, or for firms with more than one controlling shareholder whose classification differs. Beyond presenting the controlling classification for the full sample, we split the classification for both firms listed on the Novo Mercado as well as different listing segments, denoted by Other Segments. We show the number of firms within each classification as well as the percentage in relation to the total. 
Table A.4: Frequency by which ultimate shareholder controls the firms of our sample through a corporation that is not an investment fund

\begin{tabular}{cccc}
\hline Classification & Pyramid & Total & Percentage \\
\hline State & 2 & 10 & $20,00 \%$ \\
Family & 70 & 90 & $77,78 \%$ \\
Financial Institution & 4 & 14 & $28,57 \%$ \\
Corporation & 28 & 31 & $90,32 \%$ \\
Miscellaneous & 30 & 37 & $81,08 \%$ \\
Total & 134 & 182 & $73,63 \%$ \\
\hline
\end{tabular}

Note: In this table we present how often the controlling shareholder owns shares of the firms of our sample through a pyramidal structure and, at the same time, the first corporation of the chain by which he exercises control is different from an investment fund. We denote a firm that satisfies this condition by Pyramid. Total is the number of firms whose controlling is of a given category. Percentage is the ratio of Pyramid to Total. Following La Porta et al. (1998), we say that the ultimate controlling structure his equity holdings through a pyramid when he owns shares of the company via a chain of companies in which at least one of those companies in the chain is a public traded one.

Table A.5: Frequency by which ultimate shareholder controls the firms of our sample through a corporation that is not an investment fund by listing segments

\begin{tabular}{ccccccc}
\hline \multirow{2}{*}{ Classification } & \multicolumn{3}{c}{ Novo Mercado } & \multicolumn{3}{c}{ Other Segments } \\
\cline { 2 - 7 } & Pyramid & Total & Percentage & Pyramid & Total & Percentage \\
\hline State & 1 & 3 & $33,33 \%$ & 1 & 7 & $14,29 \%$ \\
Family & 39 & 47 & $82,98 \%$ & 31 & 43 & $72,09 \%$ \\
nancial Institution & 2 & 8 & $25,00 \%$ & 2 & 6 & $33,33 \%$ \\
Corporation & 11 & 14 & $78,57 \%$ & 17 & 17 & $100,00 \%$ \\
Miscellaneous & 15 & 22 & $68,18 \%$ & 15 & 15 & $100,00 \%$ \\
Total & 68 & 94 & $72,34 \%$ & 66 & 88 & $75,00 \%$ \\
\hline
\end{tabular}

Note: In this table we present how often the controlling shareholder owns shares of the firms of our sample through a pyramidal structure and, at the same time, the first corporation of the chain by which he exercises control is different from an investment fund. We denote a firm that satisfy this condition by Pyramid. Total is the number of firms whose controlling is of a given category. Percentage is the ratio of Pyramid to Total. We split the full sample between firms listed on Novo Mercado and in Other Segments. Following La Porta et al. (1998), we say that the ultimate controlling structure his equity holdings through a pyramid when he owns shares of the company via a chain of companies in which at least one of those companies in the chain is a public traded one. 
Table A.6: Voting Rights versus Cash Flow Rights of the ultimate controlling shareholder

\begin{tabular}{ccccc}
\hline \multirow{2}{*}{ Classification } & \multicolumn{2}{c}{ Voting Rights } & \multicolumn{2}{c}{ Cash Flow Rights } \\
\cline { 2 - 5 } & Mean & Median & Mean & Median \\
\hline State & $74,13 \%$ & $85,38 \%$ & $30,17 \%$ & $16,85 \%$ \\
Family & $61,29 \%$ & $60,77 \%$ & $37,10 \%$ & $29,18 \%$ \\
Financial Institution & $59,50 \%$ & $59,00 \%$ & $34,54 \%$ & $16,73 \%$ \\
Corporation & $56,49 \%$ & $58,40 \%$ & $29,20 \%$ & $22,88 \%$ \\
Miscellaneous & $43,62 \%$ & $43,90 \%$ & $11,08 \%$ & $7,48 \%$ \\
Total & $60,72 \%$ & $60,53 \%$ & $33,46 \%$ & $23,50 \%$ \\
\hline
\end{tabular}

Note: This table presents means and medians of voting and cash flow rights of the ultimate controlling shareholder for the full sample between the classification of this ultimate controlling. We follow La Porta et al. (1998) and use the Final Link 10 criterion to determine the ultimate controlling of the votes of our sample firms. In this criterion, a corporation has a controlling shareholder if this shareholder's direct and indirect voting rights sum at least 10 percent. The controlling's direct voting rights is given by its total fraction of voting shares in relation to the number of outstanding voting shares of the firm. While its indirect voting rights is given by the first shareholder's voting rights in the chain by which the controlling shareholder owns shares from the company in our sample, provided that every firm in that chain owns at least $10 \%$ of the voting rights of the predecessor firm. The ultimate controlling shareholder's cash flow rights is given by the product of the cash flow rights of each firm in the chain by which he structure his equity holdings. 
Table A.7: Voting Rights versus Cash Flow Rights of the ultimate controlling shareholder by listing segments

\begin{tabular}{|c|c|c|c|c|}
\hline \multirow[b]{2}{*}{ Classification } & \multicolumn{2}{|c|}{ Novo Mercado } & \multicolumn{2}{|c|}{ Other Segments } \\
\hline & Voting Rights & Cash Flow Rights & Voting Rights & Cash Flow Rights \\
\hline State & $56,31 \%$ & $19,56 \%$ & $83,56 \%$ & $35,78 \%$ \\
\hline Family & $49,11 \%$ & $35,79 \%$ & $77,20 \%$ & $38,81 \%$ \\
\hline Financial Institution & $44,06 \%$ & $18,70 \%$ & $90,40 \%$ & $66,23 \%$ \\
\hline Crpporation & $42,52 \%$ & $24,06 \%$ & $69,39 \%$ & $33,94 \%$ \\
\hline $\mathrm{N}_{\boldsymbol{1}}$ sellaneous & $40,01 \%$ & $8,52 \%$ & $53,27 \%$ & $17,89 \%$ \\
\hline 仓̇ Total & $47,32 \%$ & $29,13 \%$ & $76,67 \%$ & $38,62 \%$ \\
\hline
\end{tabular}

Note: This table presents means of voting and cash flow rights of the ultimate controlling shareholder between the classification of this ultimate controlling and between the companies listed in Novo Mercado and Other Segments. We follow La Porta et al. (1998) and use the Final Link 10 criterion to determine the ultimate controlling of the votes of our sample firms. In this criterion, a corporation has a controlling shareholder if this shareholder's direct and indirect voting rights sum at least 10 percent. The controlling's direct voting rights is given by its total fraction of voting shares in relation to the number of outstanding voting shares of the firm. While its indirect voting rights is given by the first shareholder's voting rights in the chain by which the controlling shareholder owns shares from the company in our sample, provided that every firm in that chain owns at least $10 \%$ of the voting rights of the predecessor firm. The ultimate controlling shareholder's cash flow rights is given by the product of the cash flow rights of each firm in the chain by which he structure his equity holdings. 
Table A.8: Individuals $(1-\alpha-\beta)$ and Investment Fund $(\beta)$ Minority shareholder's cash flow rights descriptive statistics

\begin{tabular}{ccccccc}
\hline \multirow{2}{*}{ Listing Segments } & \multicolumn{3}{c}{ Individuals } & \multicolumn{3}{c}{ Investment Funds } \\
\cline { 2 - 7 } & Mean & Median & SD & Mean & Median & SD \\
\hline Other Listing Segments & $18,44 \%$ & $14,48 \%$ & $17,07 \%$ & $0 \%$ & $0 \%$ & $0 \%$ \\
Novo Mercado & $32,21 \%$ & $29,20 \%$ & $16,64 \%$ & $0,4526 \%$ & $0 \%$ & $3,36 \%$ \\
Total & $25,58 \%$ & $26,00 \%$ & $18,15 \%$ & $0,268 \%$ & $0 \%$ & $2,60 \%$ \\
\hline
\end{tabular}

Note: This table presents descriptive statistics of Individuals and Investment Funds minority shareholders' cash flow rights by listing segment and for the full sample. The individuals are the minority shareholders who directly owns shares of the sample firms, and therefore, the parameter $(1-\alpha-\beta)$ measures its cash flow rights. Investment Fund shareholders are the minority shareholders that indirectly owns shares of the sample firms, and at the same time, the first company of the chain by which he indirectly owns shares is an Investment Fund. The parameter $(\beta)$ measures the cash flow rights of this first company of the chain.

Table A.9: Total cash flow rights of shareholders who are corporations ( $\alpha=$ $\left.\alpha_{1}+\alpha_{2}\right)$ descriptive statistics

\begin{tabular}{cccc}
\hline Listing Segments & Mean & Median & Standard Deviation \\
\hline Other Listing Segments & $52,81 \%$ & $55,97 \%$ & $28,80 \%$ \\
Novo Mercado & $38,13 \%$ & $40,40 \%$ & $27,85 \%$ \\
Total & $44,11 \%$ & $45,80 \%$ & $29,13 \%$ \\
\hline
\end{tabular}

Note: Shareholders who are corporations are the ones that indirectly owns shares of the sample firms, and at the same time, the first corporation of the chain by which they indirectly owns shares is not an investment fund. The $\alpha$ parameter is the total cash flow rights of these first companies of the chain. 
Table A.10: Sharp Regression Discontinuity Design estimates for the full sample around the 0.228625 cutoff value of the corporate tax rate

\begin{tabular}{|c|c|c|c|}
\hline \multicolumn{4}{|c|}{ Dependent Variable: Probability of Paying IOE } \\
\hline Method & Convetional & Bias-Corrected & Robust \\
\hline RD Estimates & 0,05228 & 0,04839 & 0,04839 \\
\hline Standard Error & 0,05307 & 0,05307 & 0,06324 \\
\hline P-Value & $32,50 \%$ & $36,20 \%$ & $44,40 \%$ \\
\hline $95 \% \mathrm{CI}$ & {$[-0,0517 ; 0,1563]$} & {$[-0,0556 ; 0,1524]$} & {$[-0,07556 ; 0,1723]$} \\
\hline Kernel Type & Triangular & Triangular & Triangular \\
\hline Bandwidth Type & MSE & MSE & MSE \\
\hline Order Local Poly & 1 & 1 & 1 \\
\hline Bandwidth & 0,088 & 0,088 & 0,088 \\
\hline Left Observations & 1344 & 1344 & 1344 \\
\hline Right Observations & 1715 & 1715 & 1715 \\
\hline Eff Left Observations & 554 & 554 & 554 \\
\hline Eff Right Observations & 919 & 919 & 919 \\
\hline
\end{tabular}

Note: We present three methods of the sharp regression estimates for the full sample. For details on these methods, see section 5.1 on chapter 5 . The running variable used on the estimates is the corporate tax rate, and the cutoff value is equal to 0.228625 . All methods consists of a local weighted least squares procedure, in which only observations within the chosen bandwidth around the 0.228625 cutoff are effectively used for estimation. The observations are weighted by a Triangular Kernel function. We use the MSE bandwidth type, which is the one that minimizes the mean squared error of the point estimate. Left Observations is the number of available observations to the left of the 0.228625 cutoff value, and Right Observations is the number of available observations to the right of the 0.228625 cutoff value. Eff Left Observations and Eff Right Observations stands for the effective number of observations used in the estimation to the left and to the right of the 0.228625 cutoff value, respectively. Order Local Poly stands for the degree order of the local polynomial used to approximate the true regression function. $* * * \mathrm{P}$-value $<0.01$, ** $\mathrm{P}$-value $<0.05, * \mathrm{P}$-value $<0.1$. 
Table A.11: Sharp Regression Discontinuity Design estimates for Ordinary Segments around the 0.228625 cutoff value of the corporate tax rate

\begin{tabular}{lccc}
\hline \multicolumn{3}{c}{ Dependent } & Variable: Probability of Paying IOE \\
\hline Method & Convetional & Bias-Corrected & Robust \\
RD Estimates & $0,20634^{* *}$ & $0,24373^{* *}$ & $0,24373^{* *}$ \\
Standard Error & 0,1027 & 0,1027 & 0,1173 \\
P-Value & $4,50 \%$ & $1,80 \%$ & $3,80 \%$ \\
$95 \%$ CI & {$[0,005 ; 0,4076]$} & {$[0,0424 ; 0,445]$} & {$[0,0138 ; 0,4736]$} \\
Kernel Type & Triangular & Triangular & Triangular \\
Bandwidth Type & MSE & MSE & MSE \\
Order Local Poly & 1 & 1 & 1 \\
Bandwidth & 0,062 & 0,062 & 0,062 \\
Left Observations & 654 & 654 & 654 \\
Right Observations & 898 & 898 & 898 \\
Eff Left Observations & 167 & 167 & 167 \\
Eff Right Observations & 262 & 262 & 262 \\
\hline
\end{tabular}

Note: We present three methods of the sharp regression estimates for those firms listed on ordinary segments. For details on these methods, see section 5.1 on chapter 5. The running variable used on these estimates is the corporate tax rate, and the cutoff value is equal to 0.228625 . All methods consists of a local weighted least squares procedure, in which only observations within the chosen bandwidth around the 0.228625 cutoff are effectively used for estimation. The observations are weighted by a Triangular Kernel function. We use the MSE bandwidth type, which is the one that minimizes the mean squared error of the point estimate. Left Observations is the number of available observations to the left of the 0.228625 cutoff value, and Right Observations is the number of available observations to the right of the 0.228625 cutoff value. Eff Left Observations and Eff Right Observations stands for the effective number of observations used in the estimation to the left and to the right of the 0.228625 cutoff value, respectively. Order Local Poly stands for the degree order of the local polynomial used to approximate the true regression function. *** $\mathrm{P}$-value $<0.01,{ }^{* *} \mathrm{P}$-value $<0.05,{ }^{*} \mathrm{P}$-value $<0.1$. 
Table A.12: Sharp Regression Discontinuity Design estimates for Premium Segments around the 0.228625 cutoff value of the corporate tax rate

\begin{tabular}{|c|c|c|c|}
\hline \multicolumn{4}{|c|}{ Dependent Variable: Probability of Paying IOE } \\
\hline Method & Convetional & Bias-Corrected & Robust \\
\hline RD Estimates & $-0,06832$ & $-0,09106$ & $-0,09106$ \\
\hline Standard Error & 0,07066 & 0,07066 & 0,08068 \\
\hline P-Value & $33,40 \%$ & $19,70 \%$ & $25,90 \%$ \\
\hline $95 \% \mathrm{CI}$ & {$[-0,2068 ; 0,0701]$} & {$[-0,2295 ; 0,0474]$} & {$[-0,2491 ; 0,0670]$} \\
\hline Kernel Type & Triangular & Triangular & Triangular \\
\hline Bandwidth Type & MSE & MSE & MSE \\
\hline Order Local Poly & 1 & 1 & 1 \\
\hline Bandwidth & 0,06 & 0,06 & 0,06 \\
\hline Left Observations & 690 & 690 & 690 \\
\hline Right Observations & 817 & 817 & 817 \\
\hline Eff Left Observations & 216 & 216 & 216 \\
\hline Eff Right Observations & 339 & 339 & 339 \\
\hline
\end{tabular}

Note: We present three methods of the sharp regression estimates for those firms listed on premium segments. For details on these methods, see section 5.1 on chapter 5 . The running variable used on these estimates is the corporate tax rate, and the cutoff value is equal to 0.228625 . All methods consists of a local weighted least squares procedure, in which only observations within the chosen bandwidth around the 0.228625 cutoff are effectively used for estimation. The observations are weighted by a Triangular Kernel function. We use the MSE bandwidth type, which is the one that minimizes the mean squared error of the point estimate. Left Observations is the number of available observations to the left of the 0.228625 cutoff value, and Right Observations is the number of available observations to the right of the 0.228625 cutoff value. Eff Left Observations and Eff Right Observations stands for the effective number of observations used in the estimation to the left and to the right of the cutoff value of 0.228625 , respectively. Order Local Poly stands for the degree order of the local polynomial used to approximate the true regression function. *** $\mathrm{P}$-value $<0.01,{ }^{* *} \mathrm{P}$-value $<0.05,{ }^{*} \mathrm{P}$-value $<0.1$. 
Table A.13: Sharp Regression Discontinuity Estimates around the 0.228625 cutoff using different Kernels (Robustness check 1)

\begin{tabular}{lcc}
\hline \multicolumn{2}{l}{ Dependent Variable: } & Probability of Paying IOE \\
\hline Robust RD Estimates & $0,26171^{* *}$ & $0,2393^{* *}$ \\
Standard Error & 0,12332 & 0,11688 \\
P-Value & $3,40 \%$ & $4,10 \%$ \\
$95 \%$ CI & {$[0,02 ; 0,0503]$} & {$[0,010 ; 0,4683]$} \\
Kernel Type & Uniform & Epanechnikov \\
Bandwidth Type & MSE & MSE \\
Order Local Poly & 1 & 1 \\
Bandwidth & 0,045 & 0,058 \\
Left Observations & 654 & 654 \\
Right Observations & 898 & 898 \\
Eff Left Observations & 128 & 161 \\
Eff Right Observations & 181 & 250 \\
\hline
\end{tabular}

Note: We present the robust estimates of the sharp regression discontinuity design using two different types of kernels for the weighting scheme. The sample is restricted to firms listed at ordinary segments. The running variable used on the estimates is the corporate tax rate, and the cutoff value is equal to 0.228625 . Both estimates consists of a local weighted least squares procedure, in which only observations within the chosen bandwidth around the 0.228625 cutoff are effectively used for estimation. We use the MSE bandwidth type, which is the one that minimizes the mean squared error of the point estimate. Left Observations is the number of available observations to the left of the 0.228625 cutoff value, and Right Observations is the number of available observations to the right of the 0.228625 cutoff value. Eff Left Observations and Eff Right Observations stands for the effective number of observations used in the estimation to the left and to the right of the 0.228625 cutoff value, respectively. Order Local Poly stands for the degree order of the local polynomial used to approximate the true regression function. ${ }^{* * *} \mathrm{P}$-value $<0.01$, ${ }^{* *}$ $\mathrm{P}$-value $<0.05, * \mathrm{P}$-value $<0.1$. 
Table A.14: Sharp Regression Discontinuity Estimates around the 0.228625 cutoff using different polynomial degrees (Robustness check 2)

\begin{tabular}{lccc}
\hline \multicolumn{4}{c}{ Dependent } \\
\hline Robust RD Estimates & $0,29431^{* *}$ & $0,31329^{*}$ & $0,33947^{* *}$ \\
Standard Error & 0,13262 & 0,1622 & 0,17044 \\
P-Value & $2,60 \%$ & $5,30 \%$ & $4,60 \%$ \\
$95 \%$ CI & {$[0,0343 ; 0,554]$} & {$[-0,0046 ; 0,6312]$} & {$[0,0054 ; 0,6735]$} \\
Kernel Type & Triangular & Triangular & Triangular \\
Bandwidth Type & MSE & MSE & MSE \\
Order Local Poly & 2 & 3 & 4 \\
Bandwidth & 0,095 & 0,104 & 0,14 \\
Left Observations & 654 & 654 & 654 \\
Right Observations & 898 & 898 & 898 \\
Eff Left Observations & 247 & 268 & 330 \\
Eff Right Observations & 453 & 510 & 689 \\
\hline
\end{tabular}

Note: We present the robust estimates of the sharp regression discontinuity design using three different order degree polynomials to approximate the regression function around the cutoff. The sample is restricted to firms listed at ordinary segments. The running variable used on the estimates is the corporate tax rate, and the cutoff value is equal to 0.228625 . The three estimations consists of a local weighted least squares procedure, in which only observations within the chosen bandwidth around the 0.228625 cutoff are effectively used for estimation. We use the triangular kernel for the weighting scheme, and the MSE bandwidth type, which is the one that minimizes the mean squared error of the point estimate. Left Observations is the number of available observations to the left of the 0.228625 cutoff value, and Right Observations is the number of available observations to the right of the 0.228625 cutoff value. Eff Left Observations and Eff Right Observations stands for the effective number of observations used in the estimation to the left and to the right of the 0.228625 cutoff value, respectively. Order Local Poly stands for the degree order of the local polynomial used to approximate the true regression function. ${ }^{* * *} \mathrm{P}$-value $<0.01,{ }^{* *} \mathrm{P}$-value $<0.05,{ }^{*} \mathrm{P}$-value $<0.1$. 
Table A.15: Checking the local balancing of observable characteristics around the 0.228625 cutoff (First Validation test)

\begin{tabular}{lccccc}
\hline \multicolumn{1}{c}{ Variables } & RD Estimates & Bandwidth & $\mathbf{9 5 \%}$ CI & P-Value & Observations \\
\hline Assets & 1,2276 & 0,05 & {$[-0,3232 ; 2.778]$} & $12,10 \%$ & 238 \\
Capex & $-0,00281$ & 0,069 & {$[-0,0449 ; 0,03393]$} & $89,60 \%$ & 212 \\
Tobin's Q & $-0,09533$ & 0,063 & {$[-0,417 ; 0,227]$} & $56,20 \%$ & 263 \\
Leverage & 0,02803 & 0,079 & {$[-0,056 ; 0,1120]$} & $51,30 \%$ & 467 \\
Retrined Earnings & 0,0429 & 0,066 & {$[-0,0154 ; 0,101]$} & $14,90 \%$ & 407 \\
Eq1 y & $-0,32549$ & 0,077 & {$[-1,129 ; 0,478]$} & $42,80 \%$ & 454 \\
Pre ability & 0,04131 & 0,083 & {$[-0,0436 ; 0,1262]$} & $34,00 \%$ & 506 \\
\hline
\end{tabular}

Note: This table presents the robust estimates of the sharp regressions of the variables of the first column on the corporate tax rate around the 0.228625 cutoff. The sample is restricted to firms listed at ordinary segments. We use a linear polynomial to approximate for the regression function, the triangular kernel for the weighting scheme and the bandwidth that minimizes the mean squared error of the point estimate. Observations is the total number of observations to the left and to the right of the 0.228625 cutoff effectively used for estimation. Assets is the logarithm of total assets adjusted by inflation. Capex is the ratio of capital expenditure to total assets. Tobin's Q is equal to the ratio of the firm's equity market value to its book value of equity. Leverage is the ratio of total debt to total assets. Retained earnings is the ratio of retained earnings plus earnings reserves to total assets. Equity is the logarithm of book value of equity adjusted by inflation. Profitability is the ratio of earnings before interest and taxes to total assets. ${ }^{* * *} \mathrm{P}$-value $<0.01,{ }^{*} * \mathrm{P}$-value $<0.05,{ }^{*} \mathrm{P}$-value $<0.1$. 
Table A.16: Sharp Regression Discontinuity Design using the first lag of the Probability of paying IOE as the dependent variable (Second Validation test)

\begin{tabular}{lccc}
\hline \multicolumn{4}{c}{ Dependent Variable: First Lag of the Probability of Paying IOE } \\
\hline Robust RD Estimates & 0,12104 & 0,09151 & 0,11168 \\
Standard Error & 0,10072 & 0,10578 & 0,10232 \\
P-Value & $22,90 \%$ & $38,70 \%$ & $27,50 \%$ \\
$95 \%$ CI & {$[-0,0763 ; 0,3184]$} & {$[-0,1158 ; 0,2988]$} & {$[-0,0888 ; 0,3122]$} \\
Kernel Type & Triangular & Uniform & Epanechnikov \\
Bandwidth Type & MSE & MSE & MSE \\
Order Local Poly & 1 & 1 & 1 \\
Bandwidth & 0,089 & 0,069 & 0,083 \\
Left Observations & 524 & 524 & 524 \\
Right Observations & 788 & 788 & 788 \\
Eff Left Observations & 195 & 158 & 188 \\
Eff Right Observations & 379 & 262 & 347 \\
\hline
\end{tabular}

Note: We present the robust estimates of the sharp regression discontinuity design of the first lag of the outcome variable on the corporate tax rate using three different types of kernels for the weighting scheme. The sample is restricted to firms listed at ordinary segments. The running variable used on the estimates is the corporate tax rate, and the cutoff value is equal to 0.228625 . The three estimates consists of a local weighted least squares procedure, in which only observations within the chosen bandwidth around the 0.228625 cutoff are effectively used for estimation. We use the MSE bandwidth type, which is the one that minimizes the mean squared error of the point estimate. Left Observations is the number of available observations to the left of the 0.228625 cutoff value, and Right Observations is the number of available observations to the right of the 0.228625 cutoff value. Eff Left Observations and Eff Right Observations stands for the effective number of observations used in the estimation to the left and to the right of the 0.228625 cutoff value, respectively. Order Local Poly stands for the degree order of the local polynomial used to approximate the true regression function. ${ }^{* * *} \mathrm{P}$-value $<0.01,{ }^{* *} \mathrm{P}$-value $<0.05,{ }^{*} \mathrm{P}$-value $<0.1$. 
Table A.17: McCrary Manipulation test (Third Validation test)

\begin{tabular}{lcc}
\hline McCrary Test of Score Density & Discontinuity at the cutoff \\
\hline Discontinuity Estimate & $-0,486$ & $-0,3722$ \\
P-Value & $62,70 \%$ & $70,89 \%$ \\
Kernel Type & Triangular & Triangular \\
Order Local Poly & 2 & 1 \\
Left Observations & 654 & 654 \\
Right Observations & 898 & 898 \\
Eff Left Observations & 137 & 71 \\
Eff Right Observations & 180 & 129 \\
\hline
\end{tabular}

Note: This table presents the McCrary estimates of the discontinuity of the density function of the corporate tax rate (our score variable) at the 0.228625 cutoff. The sample is restricted to firms listed at ordinary segments. Left Observations is the number of available observations to the left of the 0.228625 cutoff value, and Right Observations is the number of available observations to the right of the 0.228625 cutoff value. Eff Left Observations and Eff Right Observations stands for the effective number of observations used in the estimation to the left and to the right of the 0.228625 cutoff value, respectively. Order Local Poly stands for the degree order of the local polynomial used to approximate the true regression function. 
B

\section{Figures}

Figure B.1: Cash distribution by eligible firms to pay Interest on Equity

\section{Interest on Equity versus Dividends}

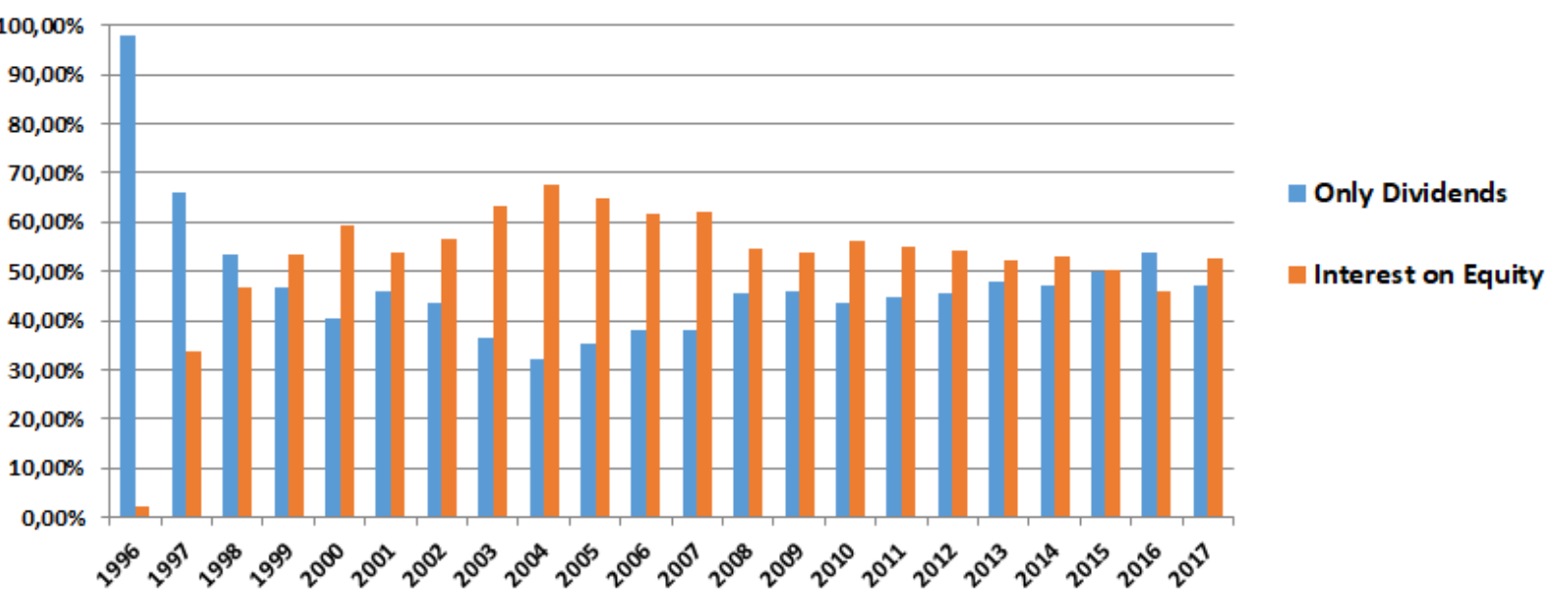


Figure B.2: Discontinuity in the probability of paying IOE at the 0.228625 cutoff for the full sample

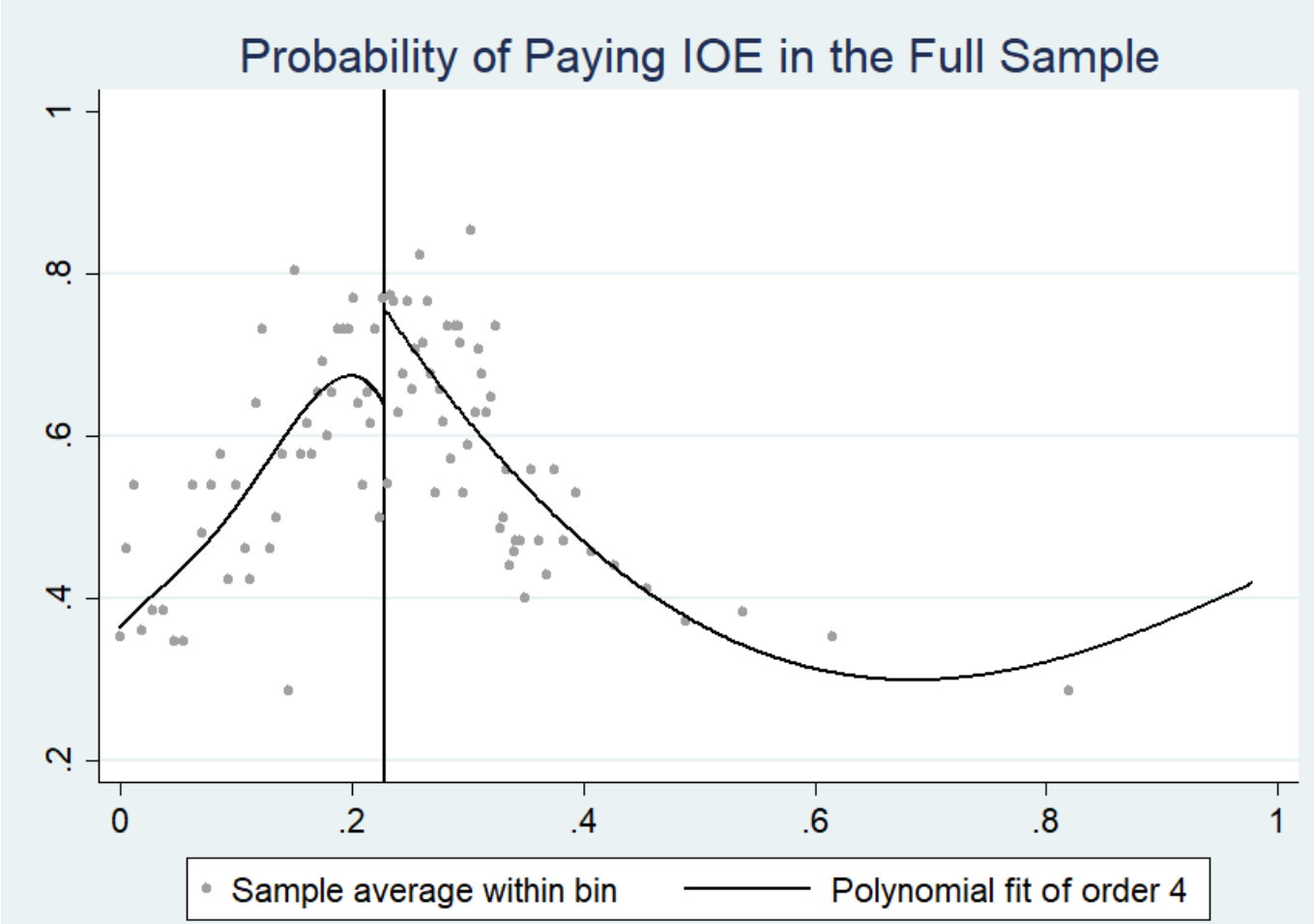


Figure B.3: Discontinuity in the probability of paying IOE at the 0.228625 cutoff for firms in Ordinary Segments

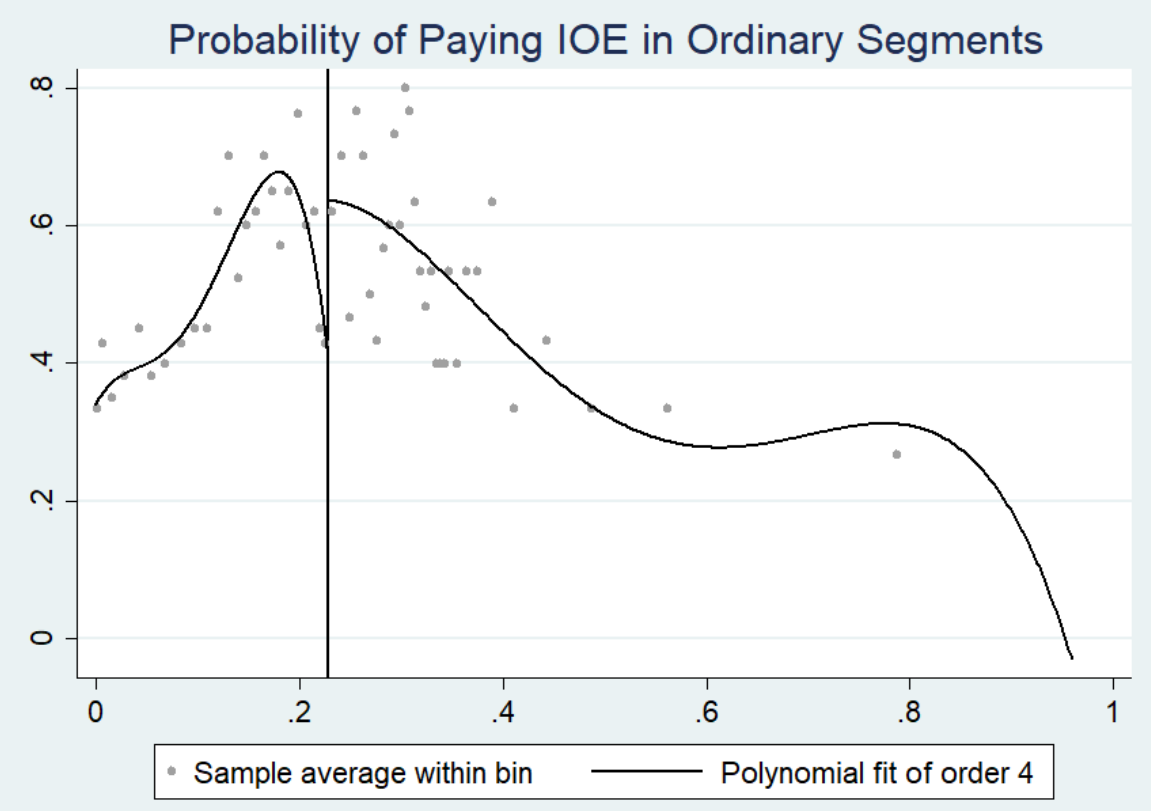

Figure B.4: Discontinuity in the probability of paying IOE at the 0.228625 cutoff for firms in Premium Segments

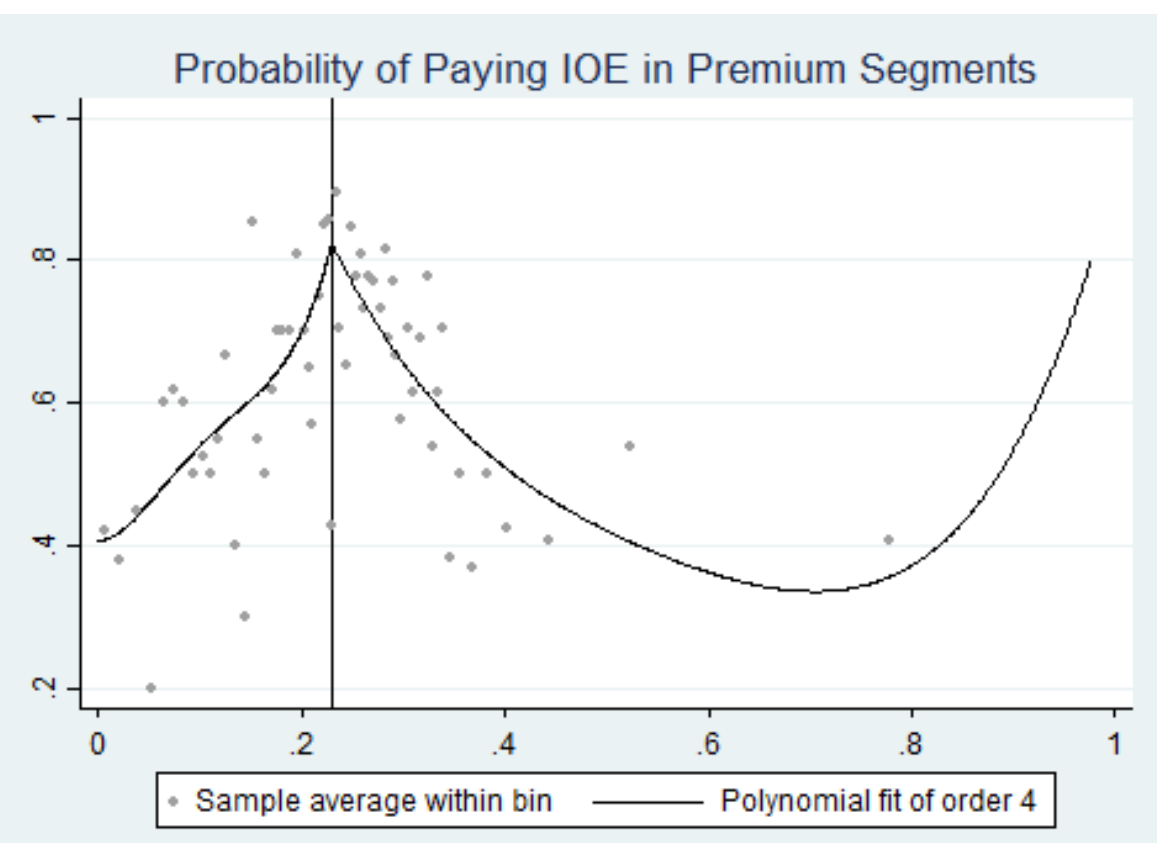


Figure B.5: Discontinuity of Assets at the 0.228625 cutoff

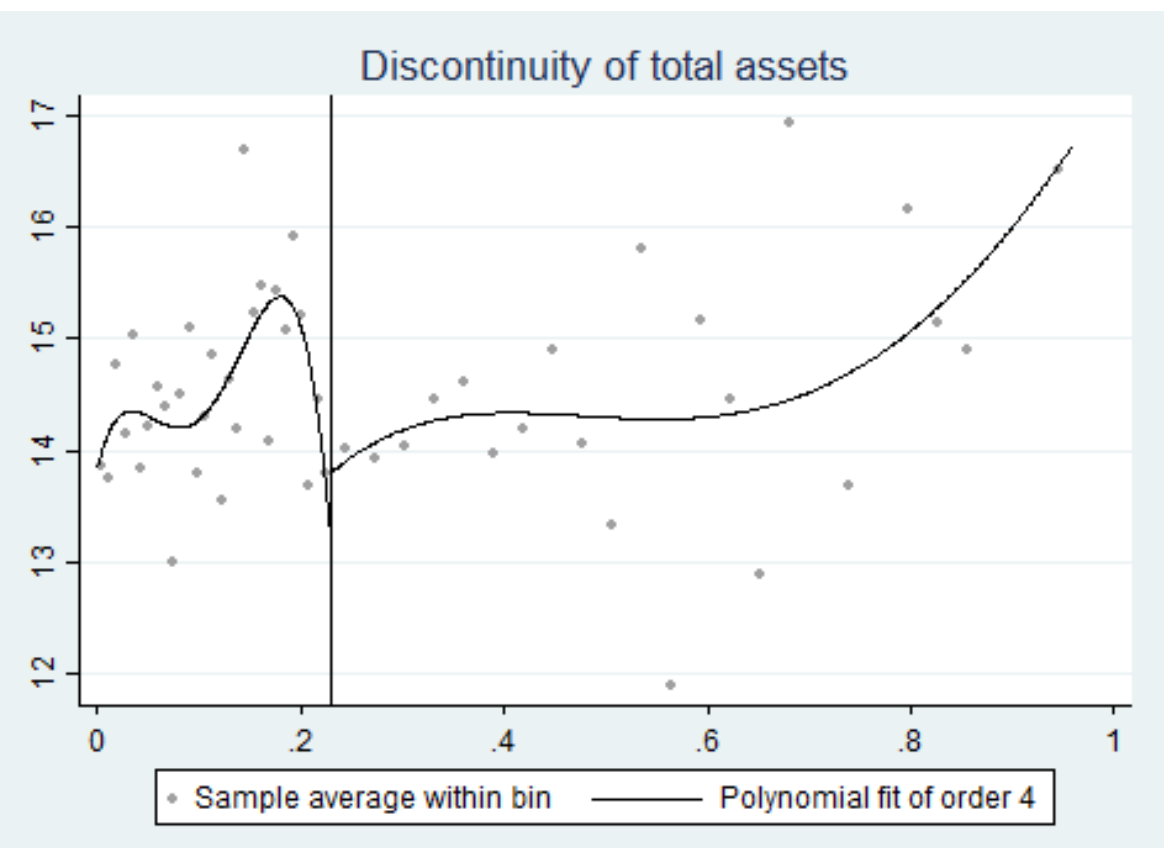

Figure B.6: Discontinuity of Capex at the 0.228625 cutoff

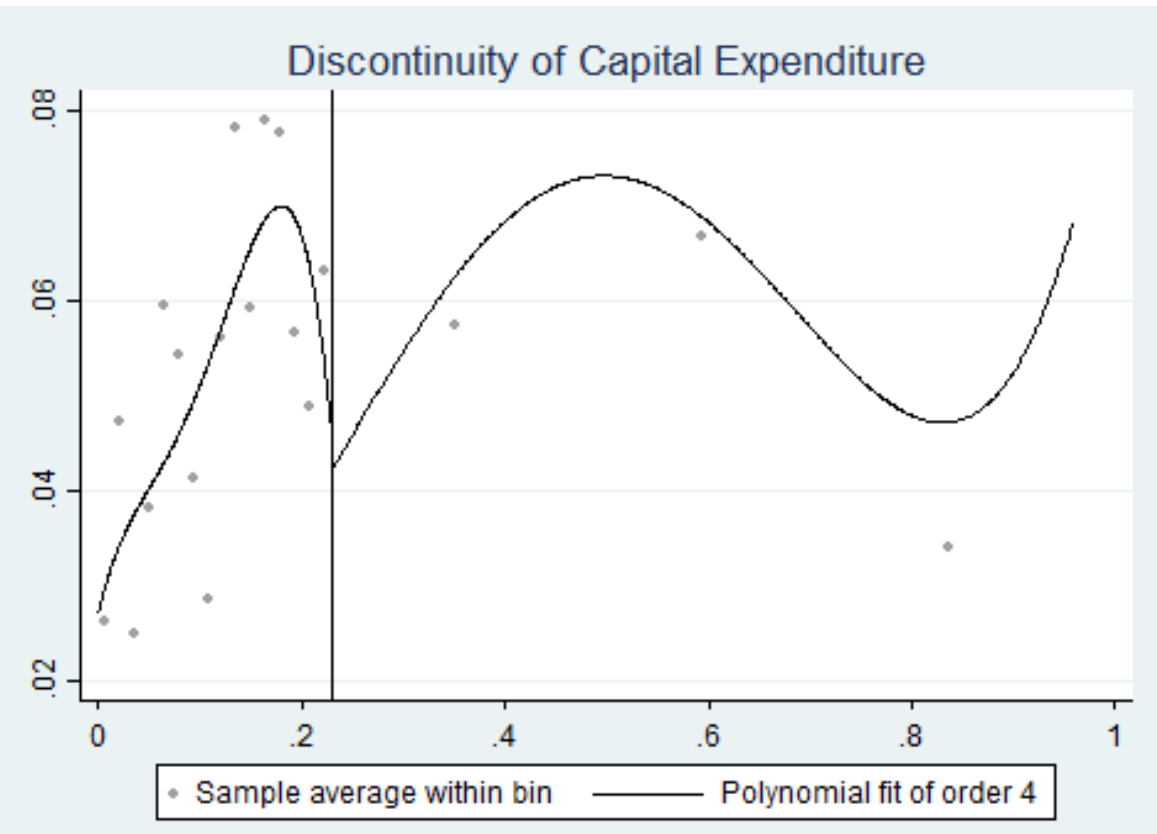


Figure B.7: Discontinuity of Tobin's Q at the 0.228625 cutoff

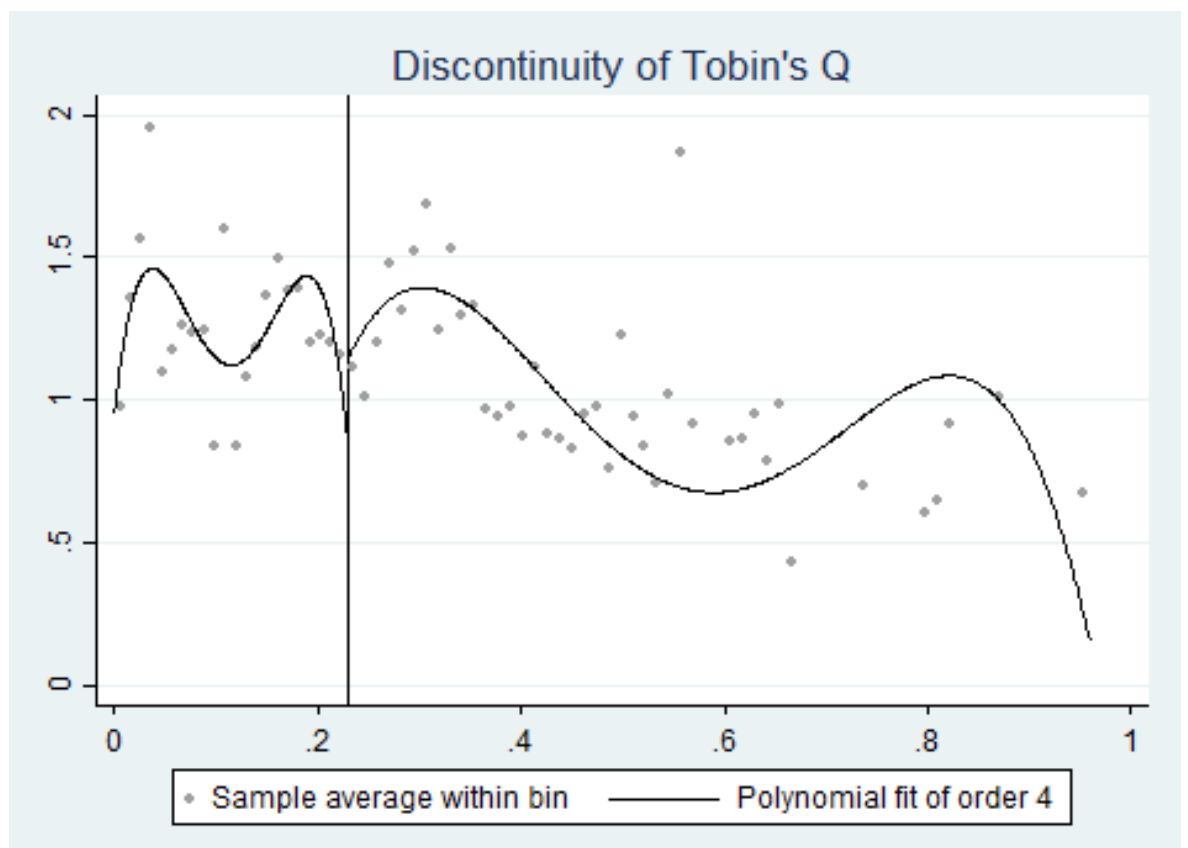

Figure B.8: Discontinuity of Leverage at the 0.228625 cutoff

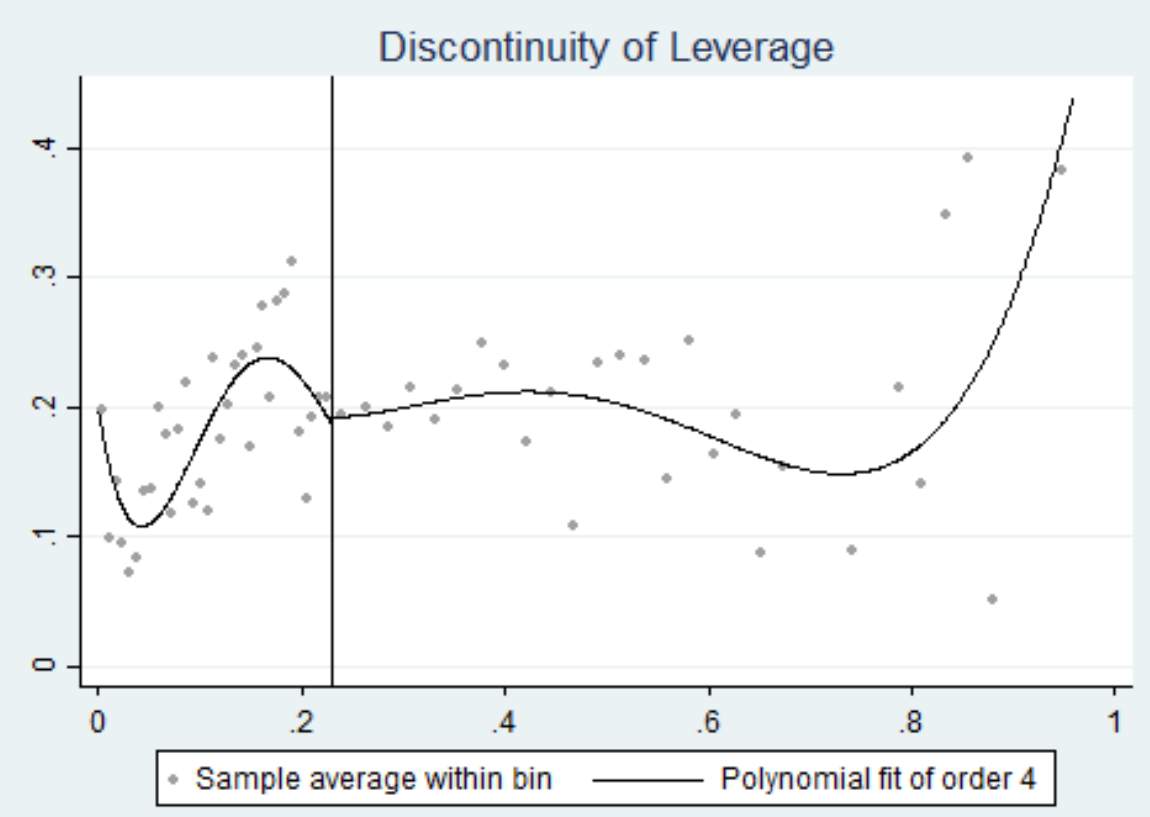


Figure B.9: Discontinuity of Retained Earnings at the 0.228625 cutoff

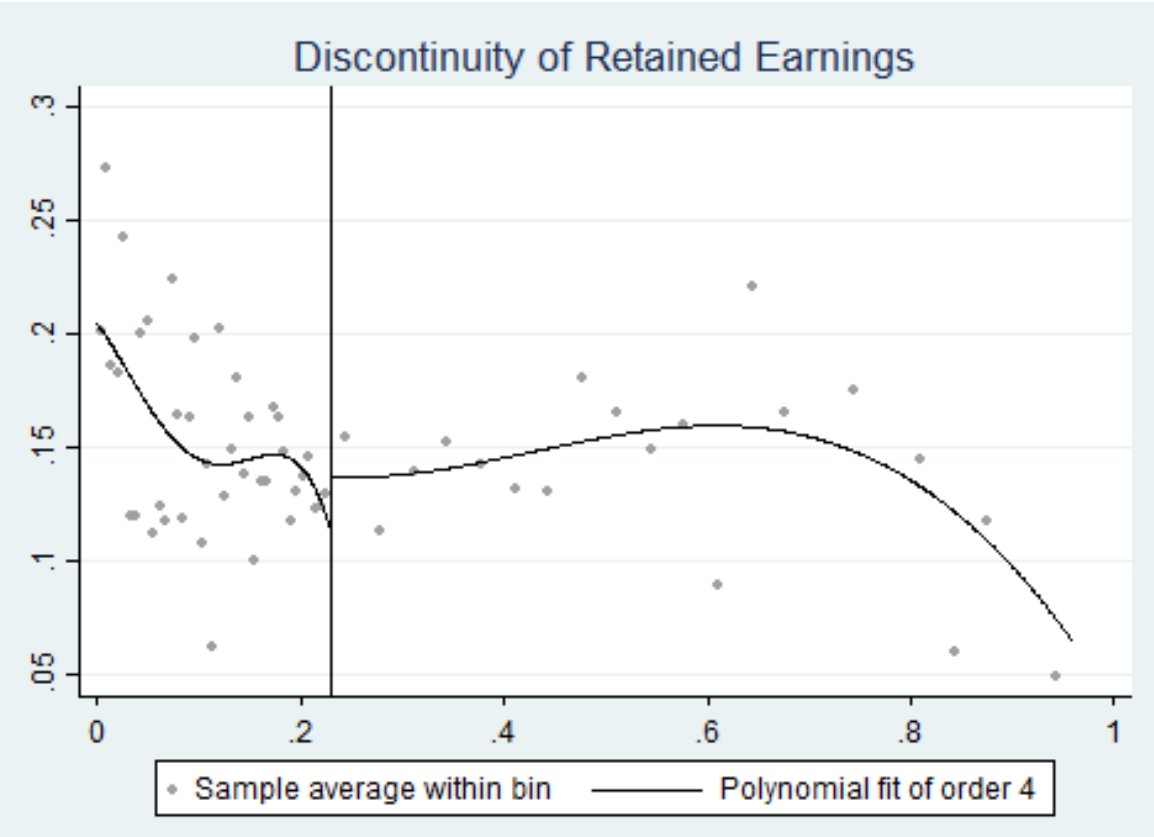

Figure B.10: Discontinuity of Equity at the 0.228625 cutoff

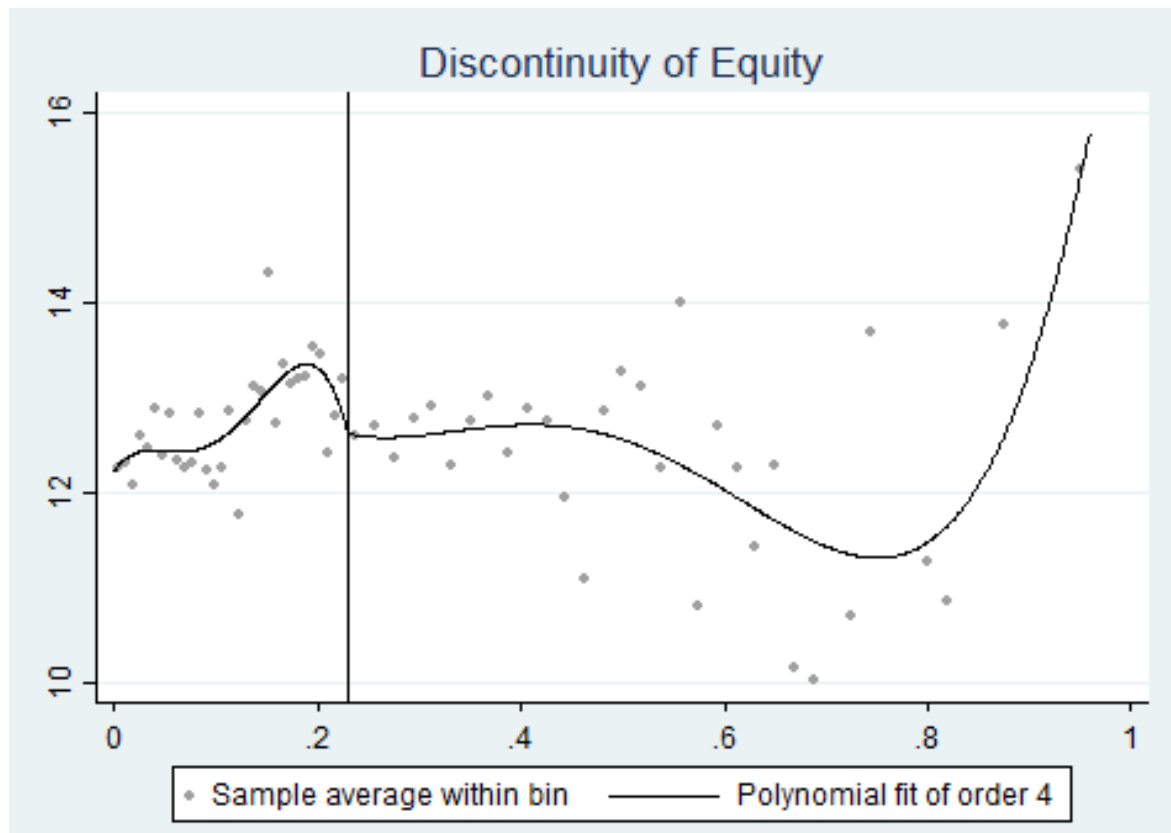


Figure B.11: Discontinuity of Profitability at the 0.228625 cutoff

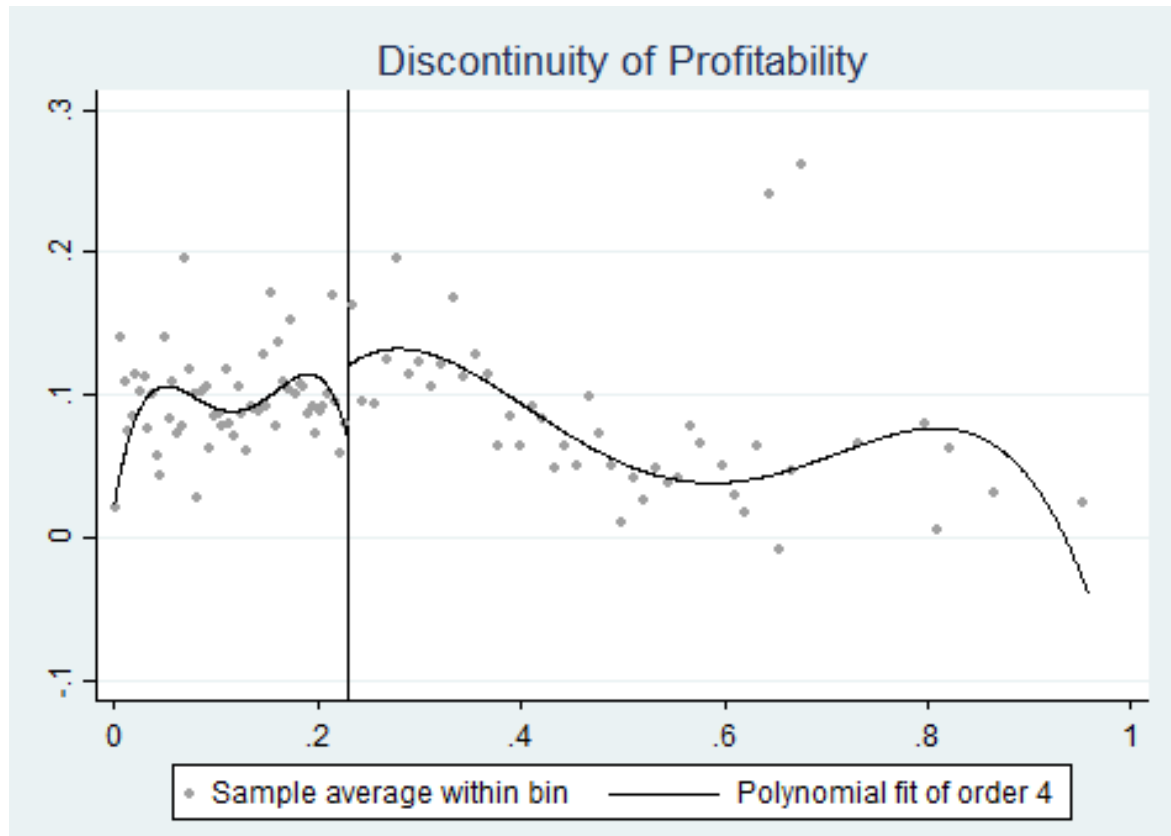

Figure B.12: Discontinuity of the First Lag of the outcome variable at the 0.228625 cutoff

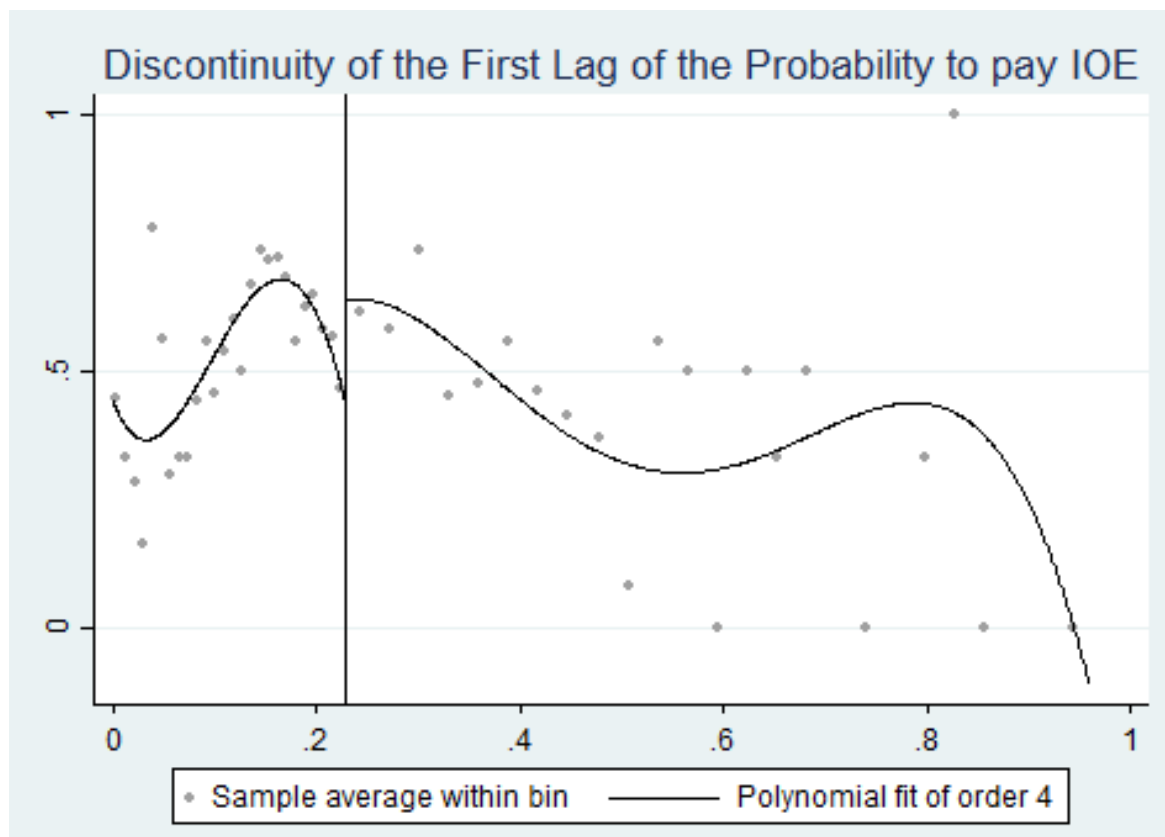


Figure B.13: Histogram of the Corporate tax rate

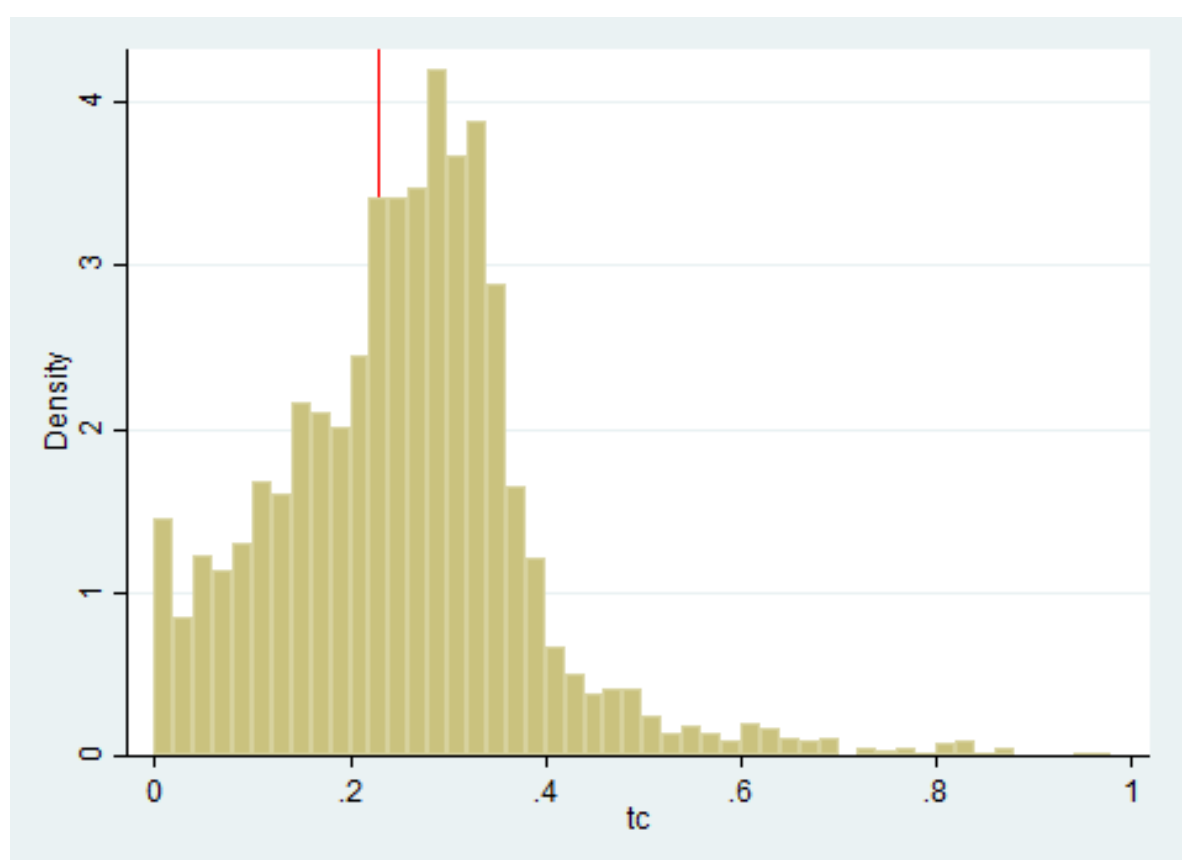

Figure B.14: Estimated Density of the Corporate tax rate

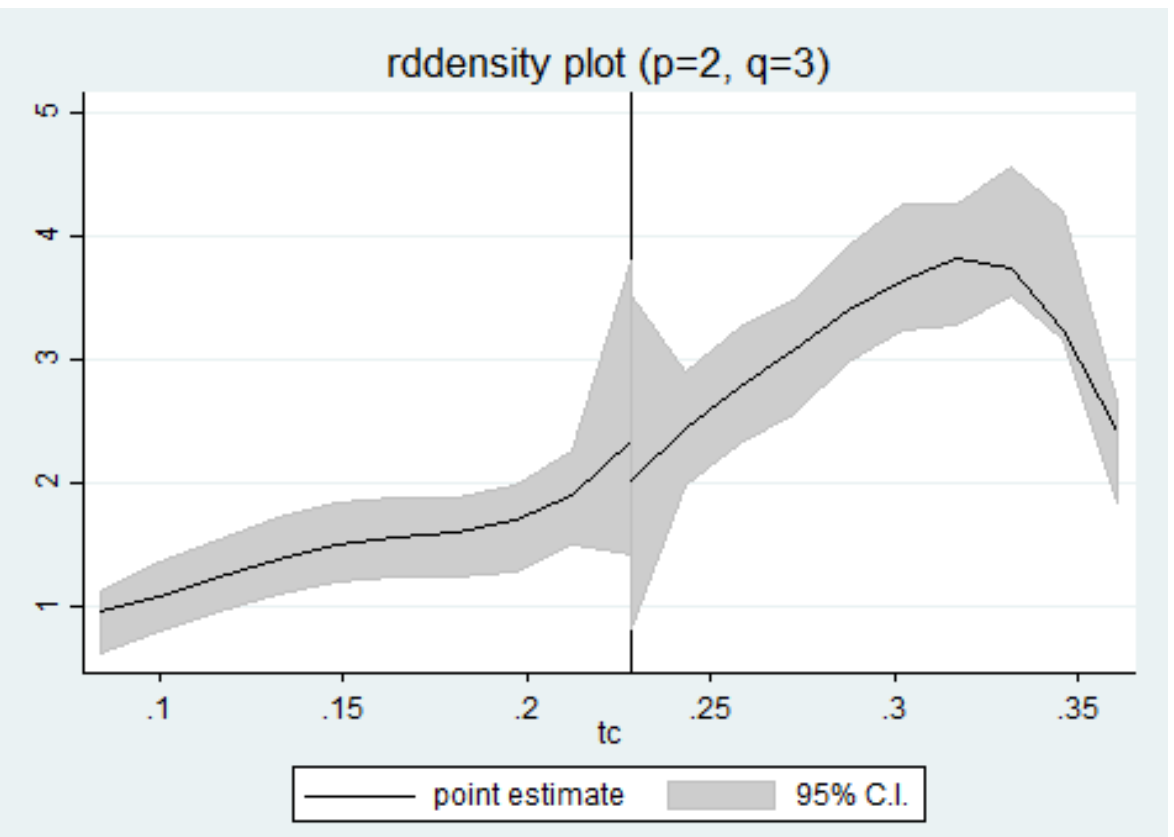

